\title{
THE OLDEST QUESTION OF CONSTITUTIONAL LAW
}

\author{
H. Jefferson Powell*
}

\section{INTRODUCTION}

$\mathrm{T}$ a polity called the United States of America, one might assume, there could be no question about the legal character of federalism. The very name suggests the federal character of what many Americans still refer to as "the Union." State institutions and entities historically have shaped much of the political, social, and cultural structure and rhythm of "national" life. It is, therefore, notable that for most of the last half-century, the United States has had no constitutional law of federalism.

In making this assertion, I am drawing on a distinction Professor Charles Black made a number of years ago:

Here is one of the most important questions conceivable, with respect to the legal basis of federalism. Is there an implied limitation on the federal powers, to the effect that they shall not be used to deal with some matters under state authority? The prevalent modern answer is negative. But the grave corollary is that federalism has no basis in firm constitutional law. The federal powers ... can be used to coerce any result, however "local," unless such an implied limitation exists, and the concept of a legally defined federalism, judicially umpired, has then no substance.

....

The issue here is not whether our federal system, with state quasisovereignty, has any basis. It has a basis in the political structure of the national government. . . . The issue, rather, is whether the federal system has any legal substance, any core of constitutional right that courts will enforce. ${ }^{1}$

\footnotetext{
* Professor, Duke University School of Law. I would like to thank Joe Goldstein for his comments and encouragement.

1 Charles L. Black, Jr., Perspectives in Constitutional Law 25, 29 (rev. ed. 1970) [hereinafter Black, Perspectives]. Professor Black himself subsequently concluded with satisfaction that there is no legal substance to American federalism. See generally Charles L. Black, Jr., On Worrying About the Constitution, 55 U. Colo. L. Rev. 469 (1984) [hereinafter Black, Constitution] (arguing that there is no identifiable pattern to the law of federalism).
} 
From the New Deal until the mid-1970s, the political branches of the federal government acted on the assumption, invariably confirmed by the Supreme Court, that there is no "legal substance, [no] core of constitutional right" limiting national power in the interests of federalism. ${ }^{2}$ When the Court undertook, in National League of Cities $v$. Usery, ${ }^{3}$ to derive an "implied limitation on the federal powers" of the type Professor Black discussed, its decision was subjected to a roar of criticism from the academy, ${ }^{4}$ rapid trivialization by the Court itself, ${ }^{5}$ and (only nine years later) explicit rejection in Garcia v. San Antonio Metropolitan Transit Authority. ${ }^{6}$

The Court's opinion in Garcia reinstituted and rendered explicit the New Deal rejection of federalism as a legal principle. ${ }^{7}$ According to the Court, "the principal means chosen by the Framers to ensure the role of the States in the federal system lies in the structure of the Federal Government itself" rather than in judicially crafted "conceptions of state sovereignty." 8 In Professor Black's terms, Garcia concluded that American federalism has a political basis but not a legal one. ${ }^{9}$

2 See, e.g., United States v. Darby, 312 U.S. 100, 123-24 (1941) (stating that the Tenth Amendment is a "truism" putting no substantive limits on congressional power.); Wickard v. Filburn, 317 U.S. 111, 120 (1942) (stating that effective restraints on commerce power "must proceed from political rather than from judicial processes").

3426 U.S. 833 (1976), overruled by Garcia v. San Antonio Metro. Transit Auth., 469 U.S. 528 (1985).

4 See, e.g., Sotirios A. Barber, National League of Cities v. Usery: New Meaning for the Tenth Amendment?, 1976 Sup. Ct. Rev. 161.

5 The Court's subsequent decisions "interpreting" National League of Cities turned the broad structural argument of the Court's opinion into a three (or four) part balancing test obviously fashioned to make it exceedingly difficult to state a viable claim under the decision. See Hodel v. Virginia Surface Mining \& Reclamation Ass'n., 452 U.S. 264, 287-88 (1981); Transportation Union v. Long Island R.R., 455 U.S. 678, 684 (1982). To be fair, one must admit that this development was foreshadowed by the concurrence in National League of Cities itself. 426 U.S. at 856 (Blackmun, J., concurring).

6469 U.S. 528 (1985).

7 Federalism as an organizing principle of American government, on the other hand, has remained healthy throughout the modern period. "As a principle of constitutional design, federalism still exists." Donald S. Lutz, The Origins of American Constitutionalism 153 (1988).

8 Garcia, 469 U.S. at 550.

9 As the first sentence in this paragraph suggested, this is a slight overstatement. Garcia expressly acknowledged the possibility that "failings in the national political process" might render a given federal intrusion into state autonomy subject to judicial review, although the Court carefully left unclear just what such failings might be. Id. at 554. The Court also stated that Garcia did not require it "to identify or define what affirmative limits the constitutional 
It would have been surprising if Garcia had actually concluded the debate $^{10}$ on what Justice Sandra Day O'Connor recently described as "perhaps our oldest question of constitutional law": the underlying basis for "the proper division of authority between the Federal Government and the States." 11 In New York v. United States ${ }^{12}$ the Supreme Court has reopened the debate. The Court's opinion, written by O'Connor, seeks to reconcile post-New Deal concepts of national power with the existence of legal limitations on that power derived from federalism. The Court noted that "[t] he Constitution ... "leaves to the several States a residuary and inviolable sovereignty" " and concluded that "[w] hatever the outer limits of that sovereignty may be, one thing is clear: The Federal Government may not compel the States to enact or administer a federal regulatory program." 13

In this Article, I discuss O'Connor's opinion in the light of the historical search for a principled law of federalism-a search that has, until now, repeatedly failed to find a satisfactory resolution. In Part I, I summarize O'Connor's New York opinion. In Part II, I outline O'Connor's development of her conception of federalism and its culmination in New York. In Part III, I consider O'Connor's claim of a historical basis for her federalism. I conclude that New York is a decision without a firm basis in founding-era discussion or the subsequent history of constitutional debate. Nevertheless, I argue in Part IV that O'Connor's conception of federalism, or something like it, can be justified on prudential grounds.

\section{THE NEW YORK DECISION}

New York v. United States involved a challenge to the constitutionality of three provisions of a federal statute, the Low-Level Radio-

structure might impose on federal action affecting the States under the Commerce Clause." Id. at 556. These reservations do not seem of very great practical or doctrinal importancethe Court's only hint about their substance was its citation, id., to Coyle v. Oklahoma, 221 U.S. 559, 580 (1911) (holding that Congress could not deny to Oklahoma the power enjoyed by other states to locate its own capital), a unique decision with no evident generative power.

10 The dissents in Garcia plainly did not accept the decision as final. See, e.g., 469 U.S. at 580 (Rehnquist, J., dissenting) (predicting that the "principle" of federalism would "in time again command the support of a majority of this Court").

11 New York v. United States, 112 S. Ct. 2408, 2414 (1992).

12 Id.

13 Id. at 2434-35 (quoting The Federalist No. 39, at 245 (James Madison) (Clinton Rossiter ed., 1961). 
active Waste Policy Amendments Act of 1985. ${ }^{14}$ A product of extended discussion among the states and in Congress about the difficult task of nuclear waste disposal, the Act incorporates a "statebased"15 solution, making each state "responsible for providing, either by itself or in cooperation with other States, for the disposal of . . . low-level radioactive waste generated within the State."16 Congress' primary role in the scheme is to establish deadlines for devising and implementing state waste-disposal plans, create incentives for state compliance with the deadlines, and approve the regional compacts that the Act recognizes as one method of compliance. ${ }^{17}$ Congress included three "incentives" for compliance with the Act's deadlines during the period in which the states prepared to meet their ultimate obligation to take responsibility for the disposal of their own low-level radioactive waste:

1. Monetary incentives. One quarter of the surcharges collected by the sited States must be transferred to an escrow account held by the Secretary of Energy. The Secretary then makes payments from this account to each State that has complied with a series of deadlines. ...

2. Access incentives. The second type of incentive involves [the imposition of surcharges for waste disposal on states failing to meet the Act's deadlines, and ultimately] the denial of access to disposal sites.

…

3. The take title provision. The third type of incentive is the most severe. The Act provides:

If a State ... in which low-level radioactive waste is generated is unable to provide for the disposal of all such waste generated within such State or compact region by January 1, 1996, each State in which such waste is generated, upon the request of the generator or owner of the waste, shall take title to the waste, be obligated to take possession of the waste, and shall be liable for

1442 U.S.C. $\$ \S 2021 \mathrm{~b}-2021 \mathrm{j}$ (1988). In this article I am not concerned with the environmental policy aspects of this very important statute or with the extralegal consequences of the Supreme Court's decision.

${ }^{15}$ New York, 112 S. Ct. at 2437 (White, J., concurring in part and dissenting in part).

1642 U.S.C. $\$ 2021 \mathrm{c}(\mathrm{a})(1)(\mathrm{A})$. There are exceptions for certain federally-generated nuclear waste. See $\S 2021 c(a)(1)(B),(b)$.

17 See 42 U.S.C. $\S 2021$ b-j. Congressional approval is necessary under art. I, $\S 10, \mathrm{cl} .3$ of the Constitution, which prohibits "any Agreement or Compact" between states that does not have congressional approval. 
all damages directly or indirectly incurred by such generator or owner as a consequence of the failure of the State to take possession of the waste [after a certain date]. ${ }^{18}$

The State of New York participated fully in the negotiations that led to the 1980 and 1985 statutes and met the 1985 Act's initial deadlines. ${ }^{19}$ After encountering opposition from residents of the two counties in which it had identified potential waste-disposal sites, however, New York and the two counties ("the State") brought a declaratory judgment action against the United States contesting the validity of the Act. The lower federal courts held that the complaint failed to state a claim. ${ }^{20}$

The issue before the Supreme Court was New York's challenge to the constitutionality of the 1985 Act's overall command that each state be "responsible for providing . . . for the disposal of . . . low-level radioactive waste."21 The State's argument was that this mandate, enforced by the three incentive provisions, violated the Tenth Amendment and the Guaranty Clause of Article IV. ${ }^{22}$ The United States argued in response that the Act merely presented the State with a set of choices: to comply or lose the right to share under the monetary incentives provision, to comply or lose access to disposal sites in other states, and, finally, to comply or take title to waste generated within the state. ${ }^{23}$

A six-Justice majority of the Court held that the take title provision of the 1985 Act was unconstitutional and severable, and that without that provision the Act was constitutional. Writing for the majority, Justice O'Connor construed the Act in accordance with the federal

$18112 \mathrm{~S}$. Ct. at 2416 (citations omitted). The take title provision quoted by the Court is 42 U.S.C. $\$ 2021 \mathrm{e}(\mathrm{d})(2)(C)$.

19112 S. Ct. at 2439 (White, J., concurring in part and dissenting in part). New York decided in 1986 to construct its own waste disposal facility rather than join a regional compact and had identified five potential sites for the facility by the beginning of 1988 . Id.

20757 F. Supp. 10 (N.D.N.Y. 1990), aff'd, 942 F.2d 114 (2d Cir. 1991), aff'd in part and rev'd in part, $112 \mathrm{~S}$. Ct. 2408 (1992).

2142 U.S.C. $\S 2021 \mathrm{c}(\mathrm{a})(1)(\mathrm{A})$.

$22112 \mathrm{~S}$. Ct. at 2420,2432 . The state expressly declined to challenge the provisions as beyond the reach of the Commerce Clause and conceded that Congress could, under the Supremacy Clause, preempt state regulation in the area. Id. at 2419-20.

${ }^{23}$ Id. at 2495. The United States also argued that New York's conduct estopped it from challenging the 1985 Act's validity. The Court rejected this argument, id. at 2432, over Justice White's strong protest. Id. at 2439 (White, J., concurring in part and dissenting in part). 
government's interpretation as "a series of incentives" to comply with federal policy rather than as "a mandate to regulate." 24 The monetary and access incentives, she reasoned, presented the State with genuine choices. If the State chose to ignore Congress' preferences, it would find itself denied various benefits, but it was nevertheless free to make that decision for itself. She viewed the take title provision in a different light:

In this provision, Congress . . . held out the threat, should the States not regulate according to one federal instruction, of simply forcing the States to submit to another federal instruction.

A State may not decline to administer the federal program. No matter which path the State chooses, it must follow the direction of Congress. $^{25}$

The take title provision thus runs afoul of what O'Connor described as the Court's consistent understanding that Congress "lacks the power directly to compel the States to require or prohibit" activity even though Congress itself "has the authority under the Constitution to pass laws requiring or prohibiting" that activity. ${ }^{26}$

Justice O'Connor's opinion in New York v. United States is careful to connect its reasoning and result to earlier decisions and to provide grounds for distinguishing cases such as Garcia that seem to employ a different approach to federalism. The case's importance, however, lies less in the lawyerly apparatus ${ }^{27}$ than in O'Connor's desire, which she evinced long before New York, to identify a law of federalism that can deal satisfactorily both with the "oldest question of constitutional

24 Id. at 2425.

25 Id. at $2428-29$.

26 Id. at 2423 (emphasis added). The majority assumed arguendo that the state's Guaranty Clause claim was justiciable, but concluded that the monetary and access provisions of the Act did not "pose any realistic risk of altering the form or the method of functioning of New York's government" and thus could not be in violation of the clause. Id. at 2433.

27 Justices Byron R. White, Harry A. Blackmun, and John Paul Stevens dissented from the invalidation of the take title provision. Their opinions, at the very least, make it difficult to view New York as following from some preexisting common understanding. See id. at 2435 (White, J., joined by Blackmun \& Stevens, JJ., concurring in part and dissenting in part); id. at 2446 (Stevens, J., concurring in part and dissenting in part). As important as the reconciliation and distinction of cases is, however, New York clearly is a case whose resolution depends on views of American federalism that run deeper than any case law. 
law" and the modern reality of national power. In the next section of this Article, I outline O'Connor's understanding of federalism.

\section{O'CONNOR's FEDERALISM}

On her appointment to the Supreme Court in 1981, Justice O'Connor joined a Court significantly influenced by federalism concerns. Although Justice William H. Rehnquist's deference to the states was particularly apparent, ${ }^{28}$ the Burger Court as an institution displayed a solicitude for state autonomy that marked a change from the jurisprudence of the later Warren Court. ${ }^{29}$ O'Connor's voting patterns reflected her agreement with this overall tendency, but from an early stage she began staking out her own distinctive twist on Burger Court federalism. O'Connor's approach consists primarily of two building blocks: first, that the federal government must respect state governments as the seat of autonomous legislative processes even where the federal government has the power completely to preempt state regulation; and, second, that under $M^{9}$ Culloch v. Maryland ${ }^{30}$ the judiciary has the duty to police Congressional encroachment on the autonomy of the states in obedience to the spirit of the Tenth Amendment. With New York v. United States, that approach has become law.

Justice O'Connor constructed the first of these building blocks in a very early opinion, her partial dissent in FERC v. Mississippi. ${ }^{31}$ $F E R C$ involved a challenge to the constitutionality of certain provisions of the Public Utility Regulatory Policies Act of 1978. The State of Mississippi and its public utilities commission argued that several of the Act's provisions infringed federalism principles by exceeding federal power under the Commerce Clause and by violating the Tenth Amendment. These provisions mandated that state regulatory bodies in certain circumstances adjudicate disputes arising under the Act, that state utilities commissions consider specified ratemaking stan-

\footnotetext{
${ }^{28}$ See David L. Shapiro, Mr. Justice Rehnquist: A Preliminary View, 90 Harv. L. Rev. 293, 294 (1970).

29 This process began very early in Chief Justice Warren E. Burger's tenure. See, e.g., Younger v. Harris, 401 U.S. 37 (1971) (holding that federal courts cannot enjoin state criminal prosecutions except in extraordinary cases).

3017 U.S. (4 Wheat.) 316 (1819).

31456 U.S. 742, 775 (1982). Chief Justice Burger and Justice Rehnquist joined O'Connor's opinion.
} 
dards, and that the commissions follow specified notice and comment procedures in considering the proposed standards. ${ }^{32}$

The Justices unanimously rejected the Commerce Clause argument $^{33}$ but divided sharply over the Tenth Amendment issue. The majority acknowledged that the federalism issue was "somewhat novel" because the Act was an attempt "to use state regulatory machinery to advance federal goals." ${ }^{34}$ The majority nonetheless held that established principles resolved the issue against the State. The adjudication requirement, Justice Harry A. Blackmun wrote for the Court, was constitutionally indistinguishable from the settled obligation of state courts with jurisdiction over analogous claims to adjudicate questions of federal law. ${ }^{35}$ The majority conceded that the Act's provision mandating state consideration of federal rate-making standards implicated "perhaps the quintessential attribute of sovereignty,"36 but concluded that earlier decisions established that the federal government, "at least in some circumstances, can structure the State's exercise of its sovereign powers." ${ }^{37}$ Because the challenged statute represented a congressional decision to permit continued state involvement in an area subject to total federal preemption, it was clear to the majority that the Act's choices represented congressional deference to the states. ${ }^{38}$ The validity of the Act's procedural requirements, Justice Blackmun concluded, followed a fortiori from the validity of the requirement that state commissions consider the federal standards. ${ }^{39}$

32 Id. at 752 .

33 Id. at 753 ("We readily conclude that ... the appellees' arguments are without merit so far as they concern the Commerce Clause."); id. at 775 (O'Connor, J., concurring in the judgment in part and dissenting in part) ("agree[ing] with the Court that the Commerce Clause supported Congress' enactment of the" statute); id. at 775 (Powell, J., concurring in part and dissenting in part) (discussing the limited nature of his disagreement with the majority).

34 Id. at $758,759$.

35 The Court relied primarily on the well-known precedent Testa v. Katt, 330 U.S. 386 (1947), but it invoked an even more famous decision, Martin v. Hunter's Lessee, 14 U.S. (1 Wheat.) 304 (1816), as the ultimate judicial source of its reasoning. 456 U.S. at 760-61.

36456 U.S. at 761.

37 Id. at $763-64$ n.28.

38 Id. at 765 \& n.29.

39 Id. at 771. Justice Lewis F. Powell dissented from the Court's decision solely on this last point. Id. at 773-75. Powell agreed with the majority that "precedents of this Court support the constitutionality" of the rest of the Act. Id. at 775. 
In an elaborate opinion, Justice O'Connor took issue both with the majority's Tenth Amendment conclusions and, more fundamentally, with its approach to the issue. The majority, she suggested, mistook Congress' decision not to preempt the field entirely as deference to the states:

The Court's conclusion ... rests upon a fundamental misunderstanding of the role that state governments play in our federalist system.

State legislative and administrative bodies are not field offices of the national bureaucracy. Nor are they think tanks to which Congress may assign problems for extended study. Instead, each State is sovereign within its own domain, governing its citizens and providing for their general welfare. While the Constitution and federal statutes define the boundaries of that domain, they do not harness state power for national purposes. ${ }^{40}$

By imposing a federal agenda on state regulators, even if only as a set of mandatory considerations, the Act "conscript[s] state utility commissions into the national bureaucratic army" in violation of National League of Cities and "the values of federalism."41 Thus emerged the first building block of O'Connor's federalism: federalism requires that the federal government respect the autonomy of state governments as the possessors of independent institutional processes, even when Congress legislates in an area in which it has the constitutional authority completely to preempt state choices. This principle, which I shall call the "autonomy of process principle," functions to restrict the choices open to the federal government. Congress must choose either to bar state regulation of a field altogether, or to allow states to act as they please within the autonomy granted to them.

Justice O'Connor rested the autonomy of process principle on two distinct bases: a set of related arguments about the functional purposes of federalism, and a historical argument. First, she identified at least four ways in which the Act's "conscription" of state administrators warped the functioning of federalism as a political system of gov-

$40 \mathrm{Id}$. at 777 (O'Connor, J., concurring in the judgment in part and dissenting in part).

41 Id. at 775 (O'Connor, J., concurring in the judgment in part and dissenting in part). O'Connor's opinion dealt briskly with the National League of Cities issue, arguing that the Act clearly flunked the multipart test subsequent cases had derived from that decision. Id. at 77881 (O'Connor, J., concurring in the judgment in part and dissenting in part). The weight of O'Connor's opinion clearly rested on her own federalism analysis and not on the National League of Cities test. 
ernance. (1) Straightforward federal preemption, O'Connor pointed out, permits states "free to exercise their power in other areas" to "devote their resources elsewhere." The Act's requirements, in contrast, absorbed state resources in the consideration of federal concerns and in adherence to federal procedures. ${ }^{42}$ (2) Federal "conscription" of state agencies "blurs the lines of political accountability" by making it unclear whether the state administrators were acting on their own or as servants of Congress. ${ }^{43}$ (3) Congressional control of state agency agendas "undermines the most valuable aspects of our federalism," the freedom of individual states to act as "laboratories" for governmental experimentation and as localized opportunities for participation in self-government. ${ }^{44}$ (4) Federal control of state governmental processes upsets "the balance of power" between federal and state authority "that buttresses our basic liberties" by diffusing power. ${ }^{45}$

Second, O'Connor presented a lengthy historical justification for the autonomy of process principle. She pointed out that advocates of a new constitutional order in the 1780s identified the Confederation Congress' dependence on state legislatures to carry out its decisions as the "principal defect of the Articles of Confederation."46 "Thus," she argued, "the Framers concluded that government by one sovereign through the agency of a second cannot be satisfactory." 47 As a result, she concluded, the Constitution substituted direct national legislation affecting individuals for state implementation of federal directives and "judicial review of state laws [in conflict with national laws] for congressional control of state legislatures":48

While this history demonstrates the Framers' commitment to a strong central government, the means that they adopted to achieve that end are as instructive as the end itself. Under the Articles of Confederation, the National Legislature operated through the States.

42 Id. at 787 (O'Connor, J., concurring in the judgment in part and dissenting in part).

43 Id. (O'Connor, J., concurring in the judgment in part and dissenting in part).

44 Id. at 787-90 (O'Connor, J., concurring in the judgment in part and dissenting in part). "Citizens, however, cannot learn the lessons of self-government if their local efforts are devoted to reviewing proposals formulated by a faraway national legislature." Id. at 790 ( $\mathrm{O}^{\prime}$ Connor, $\mathrm{J}$., concurring in the judgment in part and dissenting in part).

45 Id. at 790-91 (O'Connor, J., concurring in the judgment in part and dissenting in part).

46 Id. at 791 (O'Connor, J., concurring in the judgment in part and dissenting in part).

47 Id. at 792 (O'Connor, J., concurring in the judgment in part and dissenting in part).

48 Id. at 795 (O'Connor, J., concurring in the judgment in part and dissenting in part). 
The Framers could have fortified the central government, while still maintaining the same system, if they had increased Congress' power to demand obedience from state legislatures. In time, this scheme might have relegated the States to mere departments of the National Government, a status the Court appears to endorse today. The Framers, however, eschewed this course, [and instead] established independent state and national sovereigns. ${ }^{49}$

Thus, as Justice O'Connor reads the history of the Constitution's creation, that document's purpose and effect was not simply to eliminate the weakness of the Confederation Congress that stemmed from the Congress' unavoidable dependence on state institutions, but to eliminate altogether the use of one sovereign's institutional processes by the other. ${ }^{50}$

The autonomy of process principle that O'Connor developed in $F E R C$ had at least one significant gap: it did not detail how a legally enforceable concept of federalism could coexist with the "commitment to a strong central government" that O'Connor acknowledged as a central theme of the Constitution. The principle would allow Congress a strong role in picking policy but would weaken severely its

49 Id. (O'Connor, J., concurring in the judgment in part and dissenting in part) (footnote omitted).

50 The Constitution, she wrote, "is fundamentally inconsistent with a system in which either Congress or a state legislature harnesses the legislative powers of the other sovereign." Id. at 796 (O'Connor, J., concurring in the judgment in part and dissenting in part). The seriousness with which O'Connor put forward the autonomy of process principle was signalled by her treatment of Testa v. Katt, 330 U.S. 386 (1947). The holding of Testa that state courts may not refuse to hear federal claims if they are open to analogous state claims rests on state practice dating back to the beginning of the Republic and surely is not open for review (or is it?). Viewed in that light, O'Connor's handling of the decision was remarkably grudging. O'Connor rejected the majority's reliance on Testa to establish the constitutional harmlessness of imposing on state institutions an obligation to address federal concerns. Instead, she analyzed the majority's argument as a proposal for the "expansion of Testa," 456 U.S. at 785 n.14 (O'Connor, J., concurring in the judgment in part and dissenting in part), noting that "[a]pplication of Testa to legislative power . . . vastly expands the scope of that decision." Id. at 784 (O'Connor, J., concurring in the judgment in part and dissenting in part). While this comment is technically correct as an observation, it begs the question of whether there would be anything amiss with such an expansion. For example, the Marshall Court's exercise of judicial review of state laws was a "vast expansion" of Marbury v. Madison, 15 U.S. 137 (1803), in just this sense. O'Connor's ground for distinguishing Testa-that state "trial courts of general jurisdiction," unlike state legislatures, do not set their own agendas, 456 U.S. at 784 ( $O^{\prime} C o n n o r, J .$, concurring in the judgment in part and dissenting in part)-addresses only part of her functional argument for the autonomy of process principle and does not speak to the historical argument at all. The implicit point, apparently, is that O'Connor finds Testa itself somewhat anomalous under her view of federalism. 
ability to mandate the means of implementation. The Act under review in FERC embodied a congressional determination not just of national policy - a policy that O'Connor correctly argued could have been pursued by federal preemption-but also of the appropriate means of attaining that goal.

Judicial deference to Congress' selection of means dates back to United States v. Fisher, ${ }^{51}$ in which Chief Justice John Marshall wrote: "Congress must possess the choice of means, and must be empowered to use any means which are in fact conducive to the exercise of a power granted by the constitution."52 Despite this strong presumption in favor of Congress, O'Connor's FERC opinion provided no clear constitutional warrant for judicial interference with its selection. Three years later, in her dissent in Garcia, O'Connor provided a justification for judicial interference, and the second building block in her conception of federalism.

Garcia overruled National League of Cities and held that federalism has, in Professor Black's terms, an essentially political rather than legal basis in this country. ${ }^{53}$ Justice O'Connor joined Justice Lewis F. Powell's dissent, which defended a balancing test version of National League of Cities. ${ }^{54}$ That she also wrote separately, however, demonstrated that she was more interested in articulating her own account of federalism than in adhering to National League of Cities: ${ }^{55}$

The central issue of federalism, of course, is whether any realm is left open to the States by the Constitution-whether any area remains in which a State may act free of federal interference. "The issue ... is whether the federal system has any legal substance, any core of constitutional right that courts will enforce." The true "essence" of federalism is that the States as States have legitimate interests which the National Government is bound to respect even though its laws are supreme. $^{56}$

\footnotetext{
51 6 U.S. (2 Cranch) 358 (1805).

52 Id. at 396.

53 See supra notes 6-7 and accompanying text.

54 Garcia v. San Antonio Metro. Transit Auth., 469 U.S. 528, 562-64, 578 (1985) (Powell, J., dissenting). Chief Justice Burger and Justice Rehnquist also joined Powell's dissent.

5s "I also write separately to note my fundamental disagreement with the majority's views of federalism and the duty of this Court." Id. at 580 (O'Connor, J., dissenting, joined by Powell \& Rehnquist, JJ.).

56 Id. at 580-81 (O'Connor, J., dissenting) (citation omitted) (quoting Charles L. Black, Jr., Perspectives in Constitutional Law 30 (1963)).
} 
Garcia implicated the autonomy of process principle of $F E R C$ only marginally. The federal statute at issue directly mandated congressional policy concerning wages and hours and affected the states only as employers-although as Justice Powell's dissent noted, the statute might have "serious ... e effects on state and local planning, budgeting, and the levying of taxes." 57 O'Connor directed most of her attention, therefore, to the problem of reconciling the vast powers wielded by the post-New Deal federal government with a viable law of federalism. O'Connor's starting point was a clear statement of her acceptance of the "breathtaking expansion of the powers of Congress" in the modern era. As she noted, "the Framers of our Constitution intended Congress to have sufficient power to address national problems."58 The industrialization and nationalization of the economy that postdated the Constitution's ratification "brought with it a coordinate expansion in the scope of national problems," and, ultimately, a "generous" judicial interpretation of the commerce power "primarily to assure that the National Government would be able to deal with national economic problems." 59 While legitimate, O'Connor continued, this expansion has proceeded so far that it now threatens the original constitutional intention to preserve a significant sphere of autonomous state activity in order to diffuse power and protect freedom and authentic self-government. "[T]here is now a real risk that Congress will gradually erase the diffusion of power between State and Nation on which the Framers based their faith in the efficiency and vitality of our Republic." 60

O'Connor's dissent thus skillfully set up a conundrum. Although the Constitution's goal of national empowerment renders legitimate the modern expansion of the commerce power, the expansion of the commerce power threatens to swallow up the Constitution's goal of preserving federalism. How can the Court recognize Congress' legislative discretion to address the nation's problems using the means Congress finds appropriate while at the same time fulfilling its "constitutional responsibility to oversee the Federal Government's compli-

57469 U.S. at 578 (Powell, J., dissenting).

$58 \mathrm{Id}$. at 581 (O'Connor, J., dissenting).

59 Id. at 583 (O'Connor, J., dissenting) (citing classic congressional-power decisions of the New Deal Court).

60 Id. at 581-82, 584 (O'Connor, J., dissenting). 
ance with its duty to respect the legitimate interests of the States"? ${ }^{61}$ To resolve the puzzle, O'Connor suggested a return to $M^{\prime} C u l l o c h v$. Maryland - the judicial "source of the recent expansion of the commerce power."62 In M'Culloch, Chief Justice Marshall wrote the famous passage "Let the end be legitimate, let it be within the scope of the constitution, and all means which are appropriate, which are plainly adapted to that end, which are not prohibited, but consist with the letter and spirit of the constitution, are constitutional."63 O'Connor emphasized that Marshall had qualified his sweeping endorsement of congressional discretion to legislate beyond the letter of Article I with the caveat that congressional choices must be consistent with "the letter and spirit of the constitution."64

Thus, as O'Connor reads $M^{\prime} C$ Culloch, the Necessary and Proper Clause requires the judiciary to accord substantial respect to Congress' choice of means but also provides the constitutional mandate for judicial review of the propriety of that choice. Built into the very doctrinal basis for the "judicially crafted expansion" of federal power, O'Connor argued, is the judiciary's obligation "to enforce affirmative limits on federal regulation of the States" derived from the "spirit of the Tenth Amendment."65 Her subsequent discussion of how to apply that "spirit" in construing the validity of congressional legislation that impairs state autonomy echoed the autonomy of process principle of FERC. ${ }^{66}$ Worked out explicitly, O'Connor's argument might be that a principled and viable law of federalism should be located not in the preclusion of federal regulation from some given set of problems or concerns, but in judicial oversight of congressional respect for the "integrity" 67 of the states as the possessors of autonomous governmental processes. ${ }^{68}$

61 Id. at 581 (O’Connor, J., dissenting).

62 Id. at 585 (O'Connor, J., dissenting) (citing M'Culloch v. Maryland, 17 U.S. (4 Wheat.) $316,421(1819))$.

6317 U.S. (4 Wheat.) at 421.

64 Garcia, 469 U.S. at 585 (O'Connor, J., dissenting) (quoting M'Culloch, 17 U.S. (4 Wheat.) at 421) (emphasis supplied by Justice O'Connor).

65469 U.S. at 585-87 (O'Connor, J., dissenting).

66 Id. at 588 (O'Connor, J., dissenting). See supra notes $31-50$ and accompanying text.

67 Id. at 585 (O'Connor, J., dissenting).

68 There is, perhaps, an ambiguity on this point in Justice O'Connor's writing. The Garcia dissent locates the judicial defense of the autonomy of process principle in the courts' review of the constitututionality of Congress's choice of means under the $M^{\prime}$ 'Culloch "consistent with the spirit" language. Chief Justice Marshall was then discussing the Court's review of a 
Justice O'Connor's federalism made its first appearance in an opinion of the Court ${ }^{69}$ in Gregory v. Ashcroft, ${ }^{70}$ decided in 1991. Here, for the first time, she united the autonomy of process principle with her reading of $M^{\prime} C$ ulloch. The plaintiffs in Gregory were Missouri state judges subject to a mandatory retirement provision in the state constitution; they challenged the provision as a violation of the federal Age Discrimination in Employment Act of $1967^{71}$ and of the Equal Protection Clause. Justice O'Connor wrote an opinion rejecting both claims for a five-Justice majority. The legal discussion in the opinion began with an elaborate review of the premises of O'Connor's federalism. As in earlier opinions, O'Connor reminded the reader that " $[t]$ he Constitution created a Federal Government of limited powers. . . . The States thus retain substantial sovereign authority under our constitutional system."72 She reiterated and expanded the $F E R C$ list of the functional purposes of federalism, ${ }^{73}$ laying special stress on federalism as a means of preventing the abuse of power by diffusing it. ${ }^{74}$

congressional statute based on the exercise of a supposedly implied power, not a statute directly implementing an enumerated power. Theoretically, this leaves open the possibility that some congressional statutes are direct exercises of the power literally encompassed within some constitutional provision and thus not subject to this form of judicial review.

69 Justice O'Connor revisited the fundamental principles of federalism in her dissent in South Dakota v. Dole, 483 U.S. 203 (1987). Dole, with Chief Justice Rehnquist writing for the Court, upheld the National Minimum Drinking Age Amendment, 23 U.S.C. $\S 158$, as a valid exercise of Congress's spending power. Justice O'Connor argued that the power to regulate drinking ages "falls squarely within the scope of those powers reserved to the States by the Twenty-first Amendment," 483 U.S. at 218 (O'Connor, J., dissenting), and that the statute's partial withdrawal of federal highway funds from states failing to raise their minimum drinking ages to 21 was not reasonably related to the purpose for the expenditure of the federal highway funds. Id. at 214-15 (O'Connor, J., dissenting). For O'Connor, the statute clearly violated the autonomy of process principle: Congress "is not entitled to insist as a condition of the use of highway funds that the State impose or change regulations in other areas of the State's social and economic life." Id. at 215 (O'Connor, J., dissenting).

70111 S. Ct. 2395 (1991).

7129 U.S.C. $\$ \S 621-634$ (1988 \& Supp. II 1991).

72111 S. Ct. at 2399.

73 O'Connor wrote:

This federalist structure of joint sovereigns preserves to the people numerous advantages. It assures a decentralized government that will be more sensitive to the diverse needs of a heterogeneous society; it increases opportunity for citizen involvement in democratic processes; it allows for more innovation and experimentaion in government; and it makes government more responsive by putting the States in competiton for a mobile citizenry.

Id. See supra notes 40-45 and accompanying text (discussing FERC).

74 Id. at 2399-2400. 
She invoked "the Framers" as the historical source of the "federalist system."75 Once again, she emphasized the importance of protecting the integrity and autonomy of state governmental processes. The establishment of qualifications for judges, she wrote, "is a decision of the most fundamental sort for a sovereign entity. Through the structure of its government, and the character of those who exercise government authority, a State defines itself as a sovereign."76 This authority lies at "the heart of representative government." "77

Justice O'Connor's opinion for the Court resolved the ADEA issue in Gregory through statutory construction, holding that the indicia of a congressional intent to include state judges within the statute's protections were "at least ambiguous" and that the Court would "not attribute to Congress an intent to intrude on state governmental functions" under those circumstances. ${ }^{78}$ The central interest of O'Connor's opinion, for us, however, lies in its studied hints concerning how the Court might react if a congressional "intent to intrude" were unmistakably present. O'Connor referred to "the principles of federalism that constrain Congress' exercise of its Commerce Clause powers."79 She distinguished state political decisions "of the most fundamental sort for a sovereign entity ... [whereby] a State defines itself as a sovereign" from state legislation in "area[s] traditionally regulated by the States," but described congressional intervention even in the latter as "an extraordinary power in a federalist system." 80

Most dramatically, O'Connor plainly implied that if the ADEA were intended to cover state judges, it would be unconstitutional. ${ }^{81}$

75 Id. at 2400.

76 Id.

77 Id. at 2402 (quoting Bernal v. Fainter, 467 U.S. 216, 221 (1984) (drawing language from an earlier case)).

78 Id. at 2406.

79 Id. at 2405 (emphasis added).

80 Id. at 2400.

81 The Gregory opinion used Garcia, precedent directly contradictory to O'Connor's dicta about unconstitutionality, to support the majority's decision to resolve the case on statutory construction grounds. "We are constrained in our ability to consider the limits that the statefederal balance places on Congress' powers under the Commerce Clause. See Garcia v. San Antonio Metropolitan Transit Authority .... But there is no need to do so if we hold that the ADEA does not apply to state judges." Id. at 2403. In an opinion crafted with obvious attention to nuance, O'Connor's parenthetical description of Garcia as "declining to review limitations placed on Congress' Commerce Clause powers by our federal system" probably was intended to express criticism of the decision. Id. 
The state's power to determine the qualifications of its "most important government officials," she wrote, is "a power reserved to the States under the Tenth Amendment and guaranteed them by" the Guaranty Clause. Such a Tenth Amendment power, although subject to certain federal limits, "most notably the Fourteenth Amendment, ... may be inviolate" "[a]s against Congress' powers '[t]o regulate Commerce." "82 In dicta, therefore, Gregory demonstrated how the autonomy of process principle developed in FERC could be functionally applied using the vehicle of $M^{\prime} C u l l o c h$-style review of congressional means formulated in Garcia.

In New York v. United States, ${ }^{83}$ Justice O'Connor refined, extended, and applied the law of federalism outlined in her earlier opinions. ${ }^{84}$ Making explicit the implications of her Gregory opinion, O'Connor described the $M^{\prime} C$ ulloch question about the legitimacy of a given exercise of implied power and the Tenth Amendment question about reserved state powers as two ways of formulating the same inquiry: ${ }^{85}$

82 Id. at 2402-03. The Gregory opinion also stated that "the Fourteenth Amendment does not override all principles of federalism." Id. at 2405 . While appended to a discussion of the cases applying the "political function" exception to strict scrutiny of alienage discrimination in public employment, in context this sentence at least suggests that $O^{\prime}$ Connor would apply some version, perhaps weaker, of her $M$ 'Culloch "spirit of the Constitution" review even when Congress acts explicitly under its Reconstruction-era amendments powers.

83112 S. Ct. 2408 (1992).

84 Justice O'Connor also discussed at some length the state's Guaranty Clause claim. O'Connor's Gregory opinion already had signaled an interest in the Guaranty Clause as possible source of federalism principles. $111 \mathrm{~S}$. Ct. at 2399 (citing Deborah J. Merritt, The Guarantee Clause and State Autonomy: Federalism for a Third Century, 88 Colum. L. Rev. 1, 3-10 (1988) (arguing that the guarantee clause should protect the states' ability "to operate their governments as autonomous units rather than as branch offices of the federal government," id. at 78)).

In New York, O'Connor reviewed the common assumption that Guaranty Clause claims are not justiciable and concluded that the question of justiciability was difficult and (implicitly) not settled. $112 \mathrm{~S}$. Ct. at 2432-33. Assuming justiciability arguendo, she concluded that the monetary and access provisions of the Act did not violate the clause because they "offer[ed] the States a legitimate choice" and thus left the states free "to set their legislative agendas" and state officials "accountable to the local electorate." Id. at 2433. I find it difficult to see what the Guaranty Clause adds of value to O'Connor's approach to federalism. The autonomy of process principle that $O^{\prime}$ Connor (and Professor Merritt) find in the clause can stand on its own as an inference from American constitutional structure, as $\mathrm{New}$ York shows. Any other legitimate and appropriate federalism limits on national power, I believe, can be similarly derived.

85 "In the end, just as a cup may be half empty or half full, it makes no difference whether one views the question at issue in this case as one of ascertaining the limits of the power delegated to the Federal Government under the affirmative provisions of the Constitution or 
At least as far back as Martin v. Hunter's Lessee, . . . the Court has resolved questions "of great importance and delicacy" in determining whether particular sovereign powers have been granted by the Constitution to the Federal Government or have been retained by the States.

These questions can be viewed in either of two ways. In some cases the Court has inquired whether an Act of Congress is authorized by one of the powers delegated to Congress in Article I of the Constitution. ... In other cases the Court has sought to determine whether an Act of Congress invades the province of state sovereignty reserved by the Tenth Amendment. ... In a case like this one, involving the division of authority between federal and state governments, the two inquiries are mirror images of each other. If a power is delegated to Congress in the Constitution, the Tenth Amendment expressly disclaims any reservation of that power to the States; if a power is an attribute of state sovereignty reserved by the Tenth Amendment, it is necessarily a power the Constitution has not conferred on Congress. ${ }^{86}$

O'Connor's federalism thus disavows the National League of Cities approach, which identified the federalism limit on congressional power as an analogue to Bill of Rights limitations, a trump that invalidates legislation that is within the scope of a power delegated to Congress. ${ }^{87}$ The Tenth Amendment, O'Connor concluded, is not a textual limitation on delegated powers but rather a rule of construction directing the Court to engage in $M^{\prime} \mathrm{Culloch}$ review in the service of the autonomy of process principle. "The Tenth Amendment thus directs us to determine, as in this case, whether an incident of state sovereignty is protected by a limitation on an Article I power." 88

In New York, Justice O'Connor made clear that her federalism is primarily concerned with protecting the integrity of state processes rather than with creating a substantive realm of state legislative autonomy. Justice O'Connor drew a careful distinction between Congress' "substantial powers to govern the Nation directly, including in areas of intimate concern to the States," and the prohibited "ability to

one of discerning the core of sovereignty retained by the States under the Tenth Amendment." $112 \mathrm{~S}$. Ct. at 2419.

86 Id. at 2417 (citations omitted).

87 National League of Cities v. Usery, 426 U.S. 833, 841-42 (1976) (analogizing federalism limit on congressional power to Bill of Rights limitations), overruled by Garcia v. San Antonio Metro. Transit Auth., 469 U.S. 528 (1985).

88 New York, 112 S. Ct. at 2418. 
require the States to govern according to Congress' instructions." 89 She repeated and amplified her historical argument for the autonomy of process principle ${ }^{90}$ and insisted that the Court has "always understood that even where Congress has the authority under the Constitution to pass laws requiring or prohibiting certain acts, it lacks the power directly to compel the States to require or prohibit those acts." 11

New York also reformulated O'Connor's FERC arguments distinguishing apparent examples of federal intervention in state process autonomy: she described Testa $v$. Katt ${ }^{92}$ as involving a "well established power of Congress to pass laws enforceable in state courts" that is a simple corollary of the Supremacy Clause..$^{93}$ The power of federal courts to order state officials to comply with federal law she traced similarly to the Supremacy Clause and to Article III's grant of jurisdiction to the federal judiciary. ${ }^{94}$ The most striking aspect of this part of the opinion is the skillful way in which O'Connor cabined in the significance of federal authority that she could not reject. The obligations of state courts to enforce federal law and of state officials to obey federal court orders are "mandated by the text of the Supremacy Clause" and Article III; no more general principle about the federalstate relationship is to be drawn from them. ${ }^{95}$

New York v. United States converted Justice O'Connor's proposal for a judicially enforceable law of federalism into official Supreme Court doctrine. The opinion, like most Supreme Court opinions announcing significant change in the law, is replete with assertions of its continuity with - indeed, its virtual identity with-earlier decisions and understandings. ${ }^{96}$ The care with which $\mathrm{O}^{9}$ Connor has presented

\footnotetext{
89 Id. at 2421.

90 Id. at 2420-22. New York briefly mentioned Justice O'Connor's functional arguments for federalism but did not treat them as being of fundamental significance. "Our task would be the same even if one could prove that federalism secured no advantages to anyone. It consists not of devising our preferred system of government, but of understanding and applying the framework set forth in the Constitution." Id. at 2418.

91 Id. at 2423.

92330 U.S. 386 (1947).

93 Id. at 2429.

94 Id. at $2429-30$.

95 Id. at 2430.

96 The federalism of the New York decision, O'Connor assured the reader, is not "our preferred system of government, but . . . the framework set forth in the Constitution." Id. at 2418. The changes in the actual political relationship between the federal and state
} 
the historical case for her understanding of federalism, however, invites an equally careful examination of the history of thought about federalism that she invokes.

\section{Historical ANSWers to the Oldest Question}

Professor Black's jurisprudential puzzle over the existence of a legal as opposed to a political structure of federalism ${ }^{97}$ obviously is not a problem of his or Justice O'Connor's invention. Nor is the problem the creation of post-New Deal centralization, as O'Connor sometimes seems to suggest, or a byproduct of judicial unfaithfulness to an earlier and unambiguous constitutional vision. The intellectual and juridical problem posed by granting a federal government significant and extended powers is written into the text of the Constitution itself, and was one of the most obvious features of the 1780s debates over the Constitution's drafting and ratification as well as subsequent argument over its proper interpretation. In this Part, I discuss the historical antecedents to O'Connor's vision of federalism that emerged in the debates over the Constitution's ratification, and subsequently in the ongoing process of interpreting the Constitution.

\section{A. The New Constitution and the Question of Federalism}

In New York v. United States, Justice O'Connor's primary justification for her federalism is the claim that it is derived in a straightforward fashion from the framers' decision to draft a constitution empowering the federal government to legislate directly regarding individuals: "In providing for a stronger central government ... the Framers explicitly chose a Constitution that confers upon Congress the power to regulate individuals, not States." $" 98$ In one sense, this historical assertion is indisputable: the Constitution was intended to empower Congress to levy taxes, raise armies, and execute its laws without the state legislation and execution necessary under the Articles of Confederation. But Justice O'Connor's assertion that the Con-

\footnotetext{
governments that undeniably have happened are of no true constitutional significance: "The actual scope of the Federal Government's authority with respect to the States has changed over the years ... but the constitutional structure underlying and limiting that authority has not." Id. at 2419. It was not the Court but "the Framers [who] explicitly chose" the opinion's vision of federalism; the Court merely "has consistently respected this choice." Id. at 2423.

97 See supra text accompanying note 1.

98112 S. Ct. 2408, 2423 (1992).
} 
stitution was also meant to deny to Congress the power it possessed under the Articles of (legally) obligating the states to enact laws or execute federal measures does not follow as a matter of logical necessity. ${ }^{99}$ A satisfactory answer to this historical question requires a step back from the specific issue of federal coercion to the broader question of the contours of the Constitution's federalism.

It is, of course, a commonplace that one of the central debates of the ratification period concerned whether the Constitution would produce, by intention or effect, a national, centralized, "consolidated" government. Anti-Federalist opponents of ratification charged that the Constitution would reduce the states to the status of municipal corporations. ${ }^{100}$ In response, the Federalist supporters of adoption put forth a variety of arguments, some mutually inconsistent: the governmental structure proposed by the Constitution would "preserve completely the sovereignty of the states"; ${ }^{101}$ the Constitution merely rendered efficacious powers already delegated to Congress by the Articles and thus posed no (new) threat to the states or to federalism; ${ }^{102}$ the states never were sovereign or independent and the Constitution's strengthening of the national government was simply the

99 Indeed, in his separate opinion in New York, Justice Stevens claimed that "[n]othing in that history suggests that the Federal Government may not also impose its will upon the several States as it did under the Articles." Id. at 2446 (Stevens, J., concurring in part and dissenting in part).

100 The new-modeled federal government, according to Melanchton Smith in the New York convention, would be "a government of independent powers, which extended to all objects and resources without limitation." 1 The Debates, Resolutions, and other Proceedings, in Convention, on the Adoption of the Federal Constitution 232 (Jonathan Elliot ed., Washington, 1827) [hereinafter 1 Debates]. The role of the states would conversely be diminished, both legally and practically. The Constitution would be "as complete a consolidation as the government of this state," Thomas Tredwell noted. "The sole difference between a state government under this Constitution, and a corporation under a state government, is, that a state being more extensive than a town, its powers are likewise proportionately extended, but neither of them enjoy the least share of sovereignty." 1 Debates at *6 (Mr. Tredwell's remarks). Some Anti-Federalists, indeed, charged that "consolidation" and the destruction of federalism was the Constitution's deliberate purpose. See, e.g., Joseph Taylor, Remarks in the first North Carolina convention, in 3 The Debates Resolutions, and other Proceedings, in Convention, on the Adoption of the Federal Constitution 36 (Jonathan Elliott ed., Washington, 1830) [hereinafter 3 Debates] ("This is a consolidation of all the states. Had it said, We the States, there would have been a federal intention in it. But, sir, it is clear that a consolidation is intended.").

101 James Iredell, Remarks in the first North Carolina convention, in 3 Debates, supra note 100 , at 123 .

102 Theophilus Parsons, Remarks in the Massachusetts convention, in 1 Debates, supra note 100 , at $102-03$. 
overdue acknowledgment in practice of what was already the legitimate and solitary sovereignty of the Union; ${ }^{103}$ the whole federalism/ consolidation debate was mistaken because sovereignty in America was an attribute of the people, not of either level of government. ${ }^{104}$

Both sides to the debate were hampered by their shared assumption that "sovereignty" was a unitary and exclusive quality, capable neither of division nor of joint tenancy. ${ }^{105}$ Sovereignty meant control, and the "logic of the doctrine of sovereignty required either the state legislatures or the national Congress to predominate."106 This presupposition embarrassed the Federalists and Anti-Federalists alike, although in different ways. ${ }^{107}$ The Anti-Federalists, for the most part, shared the Federalist perception that the Union's central organs ought to be strengthened, in particular by freeing Congress from dependence on the state legislatures, but they experienced difficulty in finding ways to achieve this goal without compromising-and thus annihilating - the sovereignty of the states. The Federalists, for the most part, whether out of conviction or expediency insisted that the

103 Charles C. Pinckney, Remarks in the South Carolina convention, in 3 Debates, supra note 100 , at 369 . Public avowals of this nationalistic and non-federal view of the Union and the Constitution were rare during the ratification period. There is, however, significant evidence that many of those who became leading supporters of ratification held such views, at least before the Constitution was drafted. On the eve of the Philadelphia convention, for example, Benjamin Rush publicly described Congress as "the only sovereign power in the united states" and called for constitutional reform to entrust Congress with unimpeded authority to exercise "the sovereign power." Benjamin Rush, Address to the People of the United States (1787), reprinted in 13 The Documentary History of the Ratification of the Constitution 45-49 (John P. Kaminski \& Gaspare J. Saladino eds., 1981). See generally Gordon S. Wood, The Creation of the American Republic, 1776-1787, at 525 (1969) (delineating statements supporting a supreme national government that likewise anticipate subordinate state authority).

104 James Wilson was perhaps the most prominent proponent of this position. See, e.g., James Wilson, Remarks in the Pennsylvania convention (Dec. 1, 1787), in 2 The Documentary History of the Ratification of the Constitution 448-53 (Merrill Jensen ed., 1976).

105 The Anti-Federalist Thomas Tredwell remarked that "[t]he idea of two distinct sovereigns in the same country, separately possessed of sovereign and supreme power, in the same matters at the same time, is as supreme an absurdity, as that two distinct separate circles can be bounded exactly by the same circumference." 1 Debates, supra note 100 , at *6. Tredwell's Federalist colleague Alexander Hamilton ridiculed the same concept in often-used terms as "the political monster of an imperium in imperio." The Federalist No. 15, at 93 (Alexander Hamilton) (Jacob E. Cooke ed., 1961).

106 Wood, supra note 103, at 527 (articulating the Anti-Federalists' position that there could be "but one supreme legislative power").

107 This paragraph relies upon Herbert Storing's discussion in 1 The Complete AntiFederalist 24-37 (Herbert J. Storing ed., 1981). 
Constitution was truly "federal"-a claim difficult to reconcile with the Constitution's apparent claim to supremacy.

It was the Federalists who hit upon a rhetorical solution to their problem; a solution that Herbert Storing has labelled a "new federalism": "Within its sphere the general government is a complete national government, but that sphere is limited; and within their own spheres the states act as constitutionally independent entities."108 Under the pressure of their own desire to see the Union strengthened, most Anti-Federalists came to accept the possibility of such a mixed system of government and "despite early misgivings, became its strongest advocates." 109 Where both sides had accepted the notion of mixed government, the debate became one over the proper mixture, with Anti-Federalists contending that despite nominally federal features, the Constitution entrusted most or all important governmental concerns to a "federal" government empowered to act in a national manner, directly, rather than through the states. ${ }^{110}$

The plausibility of the Federalists' "new federalism" depended on two highly contestable assumptions. The first was that the Constitution's delegations of power to the federal government were sufficiently precise to demarcate distinct and separable spheres of activity for the national and state governments. "111 "The powers of the General Government," one Federalist insisted, "are so defined, as not to destroy the Sovereignty of the Individual States." "These powers of controul by the federal head or authority, are defined in the new constitu-

108 Id. at 32. As James Madison put it in The Federalist, "[t]he proposed Constitution therefore is in strictness neither a national nor a federal constitution; but a composition of both." The Federalist No. 39, at 257 (James Madison) (Jacob E. Cooke ed., 1961).

109 Storing, supra note 107 , at 33.

110 In the Virginia convention, Patrick Henry charged that the "new federalism" argument was a rhetorical shell game: the Federalists described the Constitution "to be national and federal, as it suited the arguments of gentlemen." In fact, Henry said, "[a]ll things in common are left with this [the proposed federal] government. There being an infinitude [of powers] in the government, there must be an infinitude of means to carry it on." 2 The Debates, Resolutions, and other Proceedings, in Convention, on the Adoption of the Federal Constitution 297 (Jonathan Elliot ed., Washington, 1828) [hereinafter 2 Debates].

111 This followed from the fact that advocates of "new federalism" thinking had not abandoned the conventional view that sovereignty over "the same matters at the same time" was a logical and practical impossibility. "New federalism" as a concept depended on the assumption that it was possible to divide governmental powers into two distinct categories and then assign each category to a different sovereign.

112 Letter from Pierce Butler to Weeden Butler (Oct. 8, 1787), in 13 The Documentary History of the Ratification of the Constitution, supra note 103, at 352. 
tion, as minutely as may be," agreed another. ${ }^{113}$ The AntiFederalists, in turn, hammered at what they viewed as the studied ambiguity of the Constitution's definitions of power. ${ }^{114}$ This debate, unlike some of the earlier squabbles over "federalism," was a real disagreement: the Federalists were claiming, and the Anti-Federalists denying, that the Constitution would safeguard a separate sphere of state activity by its textual definitions of what Congress was empowered to do.

The second assumption the "new federalism" advocates made was that the federal powers, when exercised, would not in fact occupy the entire field of significant legislative activity. Madison's argument in The Federalist was typical: "The powers delegated by the proposed Constitution to the Federal Government, are few and defined. Those which are to remain in the State Governments are numerous and indefinite. ... [They] extend to all the objects, which, in the ordinary course of affairs, concern the lives, liberties and properties of the people." "115 As a consequence, Madison concluded, under the Constitution most governmental activity would be state, not federal. ${ }^{116}$ The almost uniform Anti-Federalist response to such arguments was that Madison and his allies were either naive or disingenuous. Amos Singletary bitterly told his Federalist opponents in the Massachusetts convention that "he wished they would not play round the subject with their fine stories, like a fox round a trap." For Singletary, as for most Anti-Federalists, the actual effect the Constitution would have was clear: "[W]e [are] giving up all power, and . . . the states will be like towns in this state. Towns ... have a right to lay taxes to raise money, and the states possibly may have the same."117 The Federal-

113 Pelatiah Webster, A Citizen of Philadelphia, The Weaknesses of Brutus Exposed (Nov. 8, 1787), reprinted in 14 The Documentary History of the Ratification of the Constitution 66 (John P. Kaminski \& Gaspare J. Saladino eds., 1983).

114 Among many examples, see William Symmes, Jr.'s richly sarcastic letter to Peter Osgood, Jr. (Nov. 15, 1787), in 14 The Documentary History of the Ratification of the Constitution, supra note 113, at 107-16.

115 The Federalist No. 45, at 313 (James Madison) (Jacob E. Cooke ed., 1961).

116 Only "in times of war and danger," Madison went on, would the "operations of the Federal Government" become more important and extensive than the operations of the states. Thus, paradoxically, the "more adequate ... the federal powers may be rendered to the national defence," the smaller the sphere of actual federal operations would be. Id.

1171 Debates, supra note 100, at 111. Another Anti-Federalist remarked: "I am . . . at a loss to know how the state legislatures will spend their time." Melanchton Smith, Remarks in the New York Convention (June 25, 1787), in 2 Debates, supra note 110, at 313. The anti- 
ists' claims about the continued importance and autonomy of the states were belied by the predictable effect of "the silent but certain operation of the powers" the Constitution explicitly delegated to Congress. ${ }^{118}$ "[I]t may be easily seen, that [the authority actually enumerated in the Constitution] tends to produce in time, as universal powers in every other respect."119

The "new federalism" explanation of the Constitution indisputably became one of the major lines of argument offered by Federalists in support of ratification, ${ }^{120}$ and it is this construct that Justice O'Connor treats as the "original intention" of the framers and ratifiers. It is striking, therefore, that it does not compel acceptance of O'Connor's autonomy of process principle as a judicially enforceable rule of law binding Congress. The "new federalism" interpretation of the Constitution was a plausible response to the charge of "consolidation" only to the extent that it was plausible to maintain that the Constitution's delegations of power are, in some significant manner, restricted by their textual definition so that there is an important area of legislative activity outside the theoretical reach of Congress. But Justice O'Connor's federalism, at least as she has developed it so far, makes no claim to place areas of legislative interest beyond federal reach.

A court following O'Connor's approach is to "weigh[] state autonomy as a factor in the balance"121 when reviewing congressional legislation regulating the state. ${ }^{122}$ At least in cases in which the federal

ratification minority in the Pennsylvania convention suggested that "the state legislatures may be continued for some years, as boards of appointment." Dissent of the Minority in the Pennsyvania convention (18 Dec., 1987), in 2 The Documentary History of the Ratification of the Constitution, supra note 104 , at 628 .

1182 The Documentary History of the Ratification of the Constitution, supra note 104, at 407 (remarks of John Smilie in the Pennsylvania convention). Anti-Federalists frequently stressed the inevitability of the destruction of federalism under the Constitution. See, e.g., Letters of Centinel, reprinted in 2 The Complete Anti-Federalist, supra note 107, at 152-53 (arguing that the proposed "general government would necessarily annihilate the particular governments").

119 William Symmes, remarks in the Massachusetts convention, 1 Debates, supra note 100, at 89. Symmes had the taxing and spending powers particularly in view.

120 Professor Storing believed that "[m]ost of the major Federalists spoke the language of the new federalism." 1 The Complete Anti-Federalist, supra note 107, at 38.

121 Garcia v. San Antonio Metro. Transit Auth., 469 U.S. 528, 588 (1985) (O'Connor, J., dissenting).

122 Although all of the cases to date in which O'Connor has discussed her federalism at length involved the exercise of the commerce power, Gregory v. Ashcroft, $111 \mathrm{~S}$. Ct. 2395 
government attempts to compel state legislative adoption of federal legislative choices, that factor will invalidate federal action. On the substantive scope of congressional power, however, O'Connor has repeatedly and emphatically stated her acceptance of the post-New Deal expansion of federal power. Her federalism is one of process, not of substance: "[T] he Constitution simply does not give Congress the authority to require the States to regulate. The Constitution instead gives Congress the authority to regulate matters directly and to pre-empt contrary state regulation." 123 This turns the primary Anti-Federalist criticism-and thus the "new federalism" interpretation devised to rebut it-upside down. The Anti-Federalist concern was that the Constitution ultimately would reduce the states to the status of municipal corporations not by preempting their processes but by preempting their business. The "new federalism" response was that in theory and in practice the Constitution would leave an indefinitely large set of legislative concerns for exclusive state attention. O'Connor's federalism accepts as legitimate the effective extension of congressional authority to all areas of major legislative interest; ${ }^{124}$ yet this extension is precisely the consequence of adopting the Constitution that the Anti-Federalists predicted and "new federalism" was meant to rebut.

Justice O'Connor's federalism thus endorses exactly the result the Federalists denied that the Constitution would produce-the reduction of the states to autonomous governmental processes concerned with only those affairs left to them by Congress. Justice O'Connor, of course, can defend her process approach as the only law of federalism that is politically feasible in the late-twentieth century-as a type of substitute for the federalism the Anti-Federalists wanted and many of the Federalists promised. She is, however, mistaken in describing her approach as identical to, or even logically entailed by, the Constitution's original design as explained by its original advocates.

(1991), seems to indicate that this balancing process may apply in reviewing legislation enacted under the Reconstruction era amendments as well. See supra note 82 .

123 New York, 112 S. Ct. at 2429.

124 Even O'Connor's dissent in South Dakota v. Dole relied signficantly on the Twenty-First Amendment's special, explicit grant of authority to the states (the only such grant of power in the Constitution not connected with the federal governmental structure). The opinion thus gives no direct evidence that $O^{\prime}$ Connor believes that there is an important category of substantive areas of governmental concern that remain beyond congressional reach. 483 U.S. 203, 212-13 (1987) (O'Connor, J., dissenting). 
Indeed, Justice O'Connor's approach to federalism arguably contradicts the "new federalism" explanation of the Constitution on which she relies. The Federalists did explicitly address the question of federal employment of state processes when responding to criticism of the Constitution stemming from concern over the size and expense of the proposed federal government. Drawing in large measure on the traditional association of large and expensive government with corruption, the loss of political virtue, and tyranny, the Anti-Federalists contended that the "establishment" necessary to make the proposed system work would bankrupt the Union of its finances and political morality. ${ }^{125}$ The natural Federalist response was to downplay the anticipated size and expense of federal government. In doing so, however, the Federalists at times suggested that the federal government would be able to do exactly that which O'Connor says it cannot: "coerce" state decisions and "conscript" state officers. The Federalist will serve as a good example. ${ }^{126}$

Much of what is said in The Federalist gives an impression contrary to Justice O'Connor's belief that the Constitution requires a careful separation of state and federal governmental processes. Whereas O'Connor depicts the state and federal governments as independent institutions governed in part by a common set of laws, Hamilton viewed "the state governments and the national government [ ] . . in the light of kindred systems and as parts of ONE WHOLE." "127 Within what The Federalist conceded was the limited sphere of its legitimate authority, the federal government's proposed powers would extend to the states as subordinate institutions as well as to individuals: "If a number of political societies enter into a larger political society, the laws which the latter may enact, pursuant to the powers

125 See, e.g., Lance Banning, The Jeffersonian Persuasion 92-113 (1978) (explaining the influence of eighteenth-century British opposition thought on the Anti-Federalist position).

126 In her FERC dissent, Justice O'Connor noted that some Federalists "suggested that the National Government might rely upon . . . state officials to collect national revenue. . . None of these suggestions, however, went so far as to propose congressional control of state legislative power. The suggestions, moreover, seemed to assume that the States would consent to national use of their officials." FERC v. Mississippi, 456 U.S. 742, 796 n.35 (1982) (O'Connor, J., concurring in the judgment in part and dissenting in part) (citing The Federalist No. 45, at 312-13 (James Madison) (Jacob E. Cooke ed., 1961). The dissent does not explain the basis for the last statement, and as the discussion below will show, I believe that Justice O'Connor is not justified in dismissing The Federalist as evidence contrary to her assertions about the framers' choices.

127 The Federalist No. 82, at 555 (Alexander Hamilton) (Jacob E. Cooke ed., 1961). 
entrusted to it by its constitution, must necessarily be supreme over those societies, and the individuals of whom they are composed."128

Madison's famous discussion in Number 39 of the proposed government's mixture of national and federal features makes a similar point. Although the new system would be federal "in relation to the extent of its powers," in "the operation of these powers, it [would be] national, not federal."129 Madison apparently had the proposed federal government in mind when he wrote that " $[t]$ he idea of a national Government involves in it, not only an authority over the individual citizens; but an indefinite supremacy over all persons and things, so far as they are objects of lawful Government."130 The states' "residuary and inviolable sovereignty" is found in the existence of a set of legislative concerns unreachable by the federal government, not in a federalism limit on that government's "indefinite supremacy over all persons and things" in areas of legislative concern entrusted to it. ${ }^{131}$ The idea that a measure could be within Congress' substantive competence and yet unconstitutional because of its interference with state institutions would likely have appeared to Madison and Hamilton to be a version of the illogical and impractical notion of "an imperium in imperio."132

Justice O'Connor's view of federalism also seems difficult to reconcile with The Federalist's use of the doctrine of "coterminous powers," the eighteenth-century idea that in a well-ordered government the substantive competence of the different branches of a government should be coextensive. ${ }^{133}$ Both in her FERC dissent and in New York, O'Connor carefully distinguished legislative and judicial powers and prerogatives. Congress has the power, by way of the Supremacy Clause, "in a sense, [to] direct state judges to enforce" congressional

128 The Federalist No. 33, at 207 (Alexander Hamilton) (Jacob E. Cooke ed., 1961).

129 The Federalist No. 39, at 256-57 (James Madison) (Jacob E. Cooke ed., 1961).

130 Id. at 256. That this definition applied to the proposed system is shown, I think, by Madison's further observation that "this supremacy ... [a]mong communities united for particular purposes ... is vested partly in the general, and partly in the municipal Legislatures." Id.

131 Id. at 256.

132 The Federalist No. 15, at 93 (Alexander Hamilton) (Jacob E. Cooke ed., 1961).

133 See G. Edward White, Recovering Coterminous Power Theory, 14 Nova L. Rev. 155 (1989) (recounting ratification-period discussions of the coterminous power theory); see also Johnny C. Burris, Some Brief Observations on G. Edward White's Rediscovery of the Coterminous Power Theory, 14 Nova L. Rev. 215, 215-16 (1989) (agreeing that coterminous power theory "can be traced back to the ratification process itself"). 
statutory directives. ${ }^{134}$ On the other hand, it lacks authority to issue comparable commands to state legislative or executive officers: "No comparable constitutional provision authorizes Congress to command state legislatures to legislate."135 The federal courts, however, do have the power "to order state officials to comply with federal law," 136 as well as to review state judicial decisions on matters of federal law. ${ }^{137}$ Whatever the logic of this combination of greater federal judicial power and lesser state judicial autonomy, it is, at the least, in tension with The Federalist's vision of a proper arrangement of governmental functions. As Hamilton wrote, "If there are such things as political axioms, the propriety of the judicial power of a government being co-extensive with its legislative, may be ranked among the number."138

"General propositions do not decide concrete cases,"139 and Justice O'Connor does not rest her federalism solely on broad assertions about the original understanding of federal-state relations. The autonomy of process principle, she contends, comes directly out of the "lively debate among the Framers" on "the question whether the Constitution should permit Congress to employ state governments as regulatory agencies."140 This historical claim, unfortunately, seems almost directly contradictory to views expressed by Madison and Hamilton. On at least four occasions, The Federalist appears to assert that the proposed federal government would have the authority to use state officers to carry out federal activities.

134 New York, 112 S. Ct. at 2430.

135 Id. The FERC dissent shows that the latter statement can be glossed "or to command state administrators to regulate." See FERC v. Mississippi, 456 U.S. 742, 777 (1982) (O'Connor, J., concurring in the judgment in part and dissenting in part) (equating state "legislative and administrative bodies" for purposes of analysis).

$136 \mathrm{New}$ York, 112 S. Ct. at 2430.

137 Under jurisdictional arrangements dating back to the First Congress, only the federal Supreme Court technically exercises the latter function. (Federal habeas corpus review of state prisoners' convictions, federal equitable relief against state legal action when permitted under Younger v. Harris, 401 U.S. 37 (1971), and federal removal jurisdiction all amount, in different ways, to de facto review of state court action by lower federal courts.) In any event, The Federalist roundly endorsed the constitutionality of "establish[ing] . . . an appeal from the state courts to the subordinate national tribunals." The Federalist No. 82, at 556-57 (Alexander Hamilton) (Jacob E. Cooke ed., 1961).

138 The Federalist No. 80, at 535 (Alexander Hamilton) (Jacob E. Cooke ed., 1961).

139 Lochner v. New York, 198 U.S. 45, 76 (1905) (Holmes, J., dissenting).

140 New York, 112 S. Ct. at 2421. 
In Number 36, Hamilton rebutted Anti-Federalist complaints about the "spectre" of "double sets of revenue officers" with the observation that in many cases "the probability is, that the United States ... will make use of the State officers and State regulations, for collecting the additional imposition." 141 In Number 45, responding to similar worries about the size of the proposed government, Madison echoed Hamilton's idea: "But it is probable ... that the eventual collection [of internal taxes] under the immediate authority of the Union, will generally be made by the officers, and according to the rules, appointed by the several States."142 Madison then generalized the point: "Indeed it is extremely probable that in other instances, particularly in the organization of the judicial power, the officers of the States will be cloathed with the correspondent authority of the Union." ${ }^{143}$ Hamilton, in turn, seconded Madison's reference to the judiciary in defending the propriety of giving Congress power to create lower federal courts against the charge that such courts would be unnecessary and expensive:

I am not sure but that it will be found highly expedient and useful to divide the United States into four or five, or half a dozen districts; and to institute a federal court in each district, in lieu of one in every state. The judges of these courts, with the aid of the state judges, may hold circuits for the trial of causes in the several parts of the respective districts. ${ }^{144}$

The most striking discussion in The Federalist of the question of federal use of state officials is in Number 27. In that essay, in the context of discussing the Constitution's empowerment of Congress to deal directly with individuals and not only through the state legisla-

141 The Federalist No. 36, at 227 (Alexander Hamilton) (Jacob E. Cooke ed., 1961). An earlier statement in the same essay may make the same point. "The national Legislature can make use of the system of each State within that State." Id. at 226. In light of Hamilton's other remarks, the ambiguous expression "the system" may refer to state officers- "those who are to execute the plan," as Hamilton puts it a few sentences earlier, id.-as well as to the principles and proportions of state taxation.

142 The Federalist No. 45, at 312-13 (James Madison) (Jacob E. Cooke ed., 1961).

143 Id. at 313.

144 The Federalist No. 81, at 547 (Alexander Hamilton) (Jacob E. Cooke ed., 1961). The expression "with the aid of the state judges" is not free of ambiguity. In its immediate context, where Hamilton is arguing that lower federal courts will be both valuable and inexpensive, and in light of Madison's comment in Number 45, I believe the most natural interpretation of Hamilton's statement is that he thought it might be expedient, and would be legitimate, to commission state judges to sit with federal judges on (federal court) circuit. 
tures, Hamilton lauded the Constitution precisely because it would enable the federal government to act in a dual fashion, through its own instrumentalities or through state processes:

The plan reported by the Convention, by extending the authority of the foederal head to the individual citizens of the several States, will enable the government to employ the ordinary magistracy of each in the execution of its laws. It is easy to perceive that this will tend to destroy, in the common apprehension, all distinction between the sources from which they might proceed; and will give the Foederal Government the same advantage for securing a due obedience to its authority, which is enjoyed by the government of each State.... It merits particular attention in this place, that the laws of the confederacy, as to the enumerated and legitimate objects of its jurisdiction, will become the SUPREME LAW of the land; to the observance of which, all officers legislative, executive and judicial in each State, will be bound by the sanctity of an oath. Thus the Legislatures, Courts and Magistrates of the respective members will be incorporated into the operations of the national government, as far as its just and constitutional authority extends; and will be rendered auxiliary to the enforcement of its laws. ${ }^{145}$

The founders' eighteenth-century answers seldom track with precision our twentieth-century questions, but The Federalist Number 27 is remarkably close to a point-by-point refutation of Justice O'Connor's views. For Hamilton, the extension of congressional power to direct legislation would enable Congress to use the "ordinary magistracy of each" government in executing its law, not restrict it to federal processes, as O'Connor claims. Hamilton saw the Supremacy Clause not as a mere requirement that state officials acting in their autonomous spheres follow federal law, but rather as a source of congressional authority to employ state institutions as "auxiliary to the enforcement of its laws" within the area of Congress' substantive legislative competence. In contrast to O'Connor's vision of state legislative and executive bodies as possessing autonomous governmental processes, Hamilton saw all state institutions and officers-"Legislatures, Courts and Magistrates" alike-“incorporated into the operations of the national government," operations that necessarily

145 The Federalist No. 27, at 174-75 (Alexander Hamilton) (Jacob E. Cooke ed., 1961). 
involved "an indefinite supremacy over all persons and things.".146 Hamilton, unlike O'Connor, thought it legitimate and advisable to blur the lines of federal and state responsibility.

The Federalist is not entirely free of ambiguity on the question Justice O'Connor has raised about the founders' understanding of the Constitution's federalism. ${ }^{147}$ More fundamentally, even a demonstration that The Federalist contradicts O'Connor's views generally or specifically would not refute absolutely her claim to rely on the founders-The Federalist might represent a minority position on the matter. However, this Article's general review of the Federalist/AntiFederalist debate supports its specific reading of The Federalist. Consequently, the reasonably clear and reasonably direct contradiction between O'Connor's federalism and the federalism of Hamilton and Madison, I suggest, amounts to a tentative refutation of the "framers' intent" basis for her law of federalism. Justice O'Connor has not shown that her answer to our oldest question is itself the original and oldest answer.

\section{B. The Historical Search for a Law of Federalism}

The text of the Constitution and the ratification-era debates over its interpretation both seemed to confirm that the new federal government was a government with "certain enumerated objects only," not a purely national government with substantive jurisdiction over all matters "so far as they are objects of lawful Government."148 This understanding was confirmed by the proposal and rapid adoption of the Tenth Amendment. Even if a "truism," as it was later described, ${ }^{149}$ the Tenth Amendment would be a mockery or even a fraud if the set

146 The latter quote is from The Federalist Number 39, at 256, written by Madison. See discussion supra note 131. Hamilton's view of federal supremacy was at least as nationalistic.

147 In addition to the interpretive problems I have already noted, one of Hamilton's essays supports ratification with the argument that under the Articles the state legislatures were occupied with the "business of the United States" as well as with their own, and that under the Constitution, Congress "will do all the business of the United States." The Federalist No. 84, at 586 (Alexander Hamilton) (Jacob E. Cooke ed., 1961) (emphasis added). Read in isolation, this passage provides modest support for Justice O'Connor's autonomy of process principle. Read in the context of the other Federalist passages discussed in the text, and the general ratification-era debate about federalism, I believe that the passage is of marginal importance.

148 The Federalist No. 39, at 256 (James Madison) (Jacob E. Cooke ed., 1961).

149 United States v. Darby, 312 U.S. 100, 124 (1941). 
of "powers ... reserved to the states"150 were an empty set. ${ }^{151}$ At the same time, however, both the text and the Federalists' ratification arguments made plain the intention of creating a central government with sufficient power and sufficient flexibility to address the needs of the Union as a whole. ${ }^{152}$ The need to "discern[ ] the proper division of authority between the Federal Government and the States," as New York v. United States observed, is thus a "constitutional question ... as old as the Constitution,"153 a question that is often extremely difficult to answer satisfactorily. The answer Justice O'Connor proposes can be evaluated adequately only if we set it in the context of earlier attempts to solve the problems of federalism. Over the Constitution's two centuries of existence a variety of approaches to the issue have been proposed. Perhaps unsurprisingly, most of the possible options were advanced early in the Republic's history.

\section{The Nationalistic Rejection of a Law of Federalism}

Perhaps the simplest resolution of the question of federalism is the one the Anti-Federalists claimed was implicit in the Constitution's text: The United States has no legally enforceable federal structure even if as a political matter American government is arranged in a federal manner. The Supreme Court's first important decision, Chisholm v. Georgia ${ }^{154}$ suggested as much. Chisholm was a contract action brought against the state of Georgia under the Court's original jurisdiction by a citizen of South Carolina. The Court held that it had jurisdiction under Article III despite Georgia's refusal to consent to

\footnotetext{
150 U.S. Const. amend. X.
}

151 Justice O'Connor seems correct in arguing that the most natural reading of the Tenth Amendment is that, while "essentially a tautology ... [it] confirms that the power of the Federal Government is subject to limits that may, in a given instance, reserve power to the States." New York, 112 S. Ct. at 2418.

152 While Federalists sometimes downplayed the novelty of the proposed expansions of federal power, see, e.g., The Federalist No. 40, at 262 (James Madison) (Jacob E. Cooke ed., 1961), the heart of the argument for ratification was the assertion that the Constitution would augment federal power. See, e.g., James Wilson, Remarks in the Pennsylvania convention, in 2 The Documentary History of the Ratification of the Constitution, supra note 104, at 581. Non-American observers frequently noted the proposed magnification of federal authority. See, e.g., letter from St. Jean de Crevecoeur to le Marećhal de Castries (Sept. 25, 1787), in 13 The Documentary History of the Ratification of the Constitution, supra note 103, at 227; letter from Antoine de la Forest to Comte de Montmorin (Sept. 28, 1787), in id. at 259.

153112 S. Ct. at 2414.

1542 U.S. (2 Dall.) 419 (1793). 
the suit. Two of the Justices in the majority, ${ }^{155}$ John Blair and William Cushing, rested the holding on the wording of the diversity and original jurisdiction clauses. ${ }^{156}$

Justice James Wilson and Chief Justice John Jay took a different tack, choosing to use Chisholm to articulate nationalistic accounts of the Constitution that were rhetorically remote from the "new federalism" themes of the ratification struggle of only five years before. Wilson concentrated his fire on the "perverted use," in American political and legal discussion, of the concepts of "state" and "sovereign(ty)."157 The very notion of state sovereignty, he argued, was contrary to the American commitment to popular government $t^{158}$ as well as to the text and "general texture" of the Constitution. ${ }^{159} \mathrm{He}$ concluded: "As to the purposes of the Union, therefore, Georgia is NOT a sovereign state." 160 Chief Justice Jay reached the same conclusion through an argument almost Legal-Realist in flavor. Relying on the "agreed" proposition that "one free citizen may sue any number on whom process can be conveniently executed," Jay denied that there could be any legal or constitutional distinction between suing the "forty odd thousand free citizens" of the city of Philadelphia and the "fifty odd thousand free citizens" of the state of Delaware: ${ }^{161}$

In this land of equal liberty, shall forty odd thousand in one place be compellable to do justice, and yet fifty odd thousand in another place be privileged to do justice only as they may think proper? Such objections would not correspond with the equal rights we claim; with the equality we profess to admire and maintain, and with that popular sovereignty in which every citizen partakes. ${ }^{162}$

155 Justice James Iredell dissented. Id. at 429. The four Justices in the majority delivered seriatim opinions.

156 "The judicial Power shall extend ... to Controversies . . . between a State and Citizens of another State .... In all Cases ... . in which a State shall be a Party, the supreme Court shall have original Jurisdiction." U.S. Const. art. III, § 2, cl. 1-2. See Chisholm, 2 U.S. (2 Dall.) at 450 (Blair, J.); id. at 466 (Cushing, J.).

157 Chisholm, 2 U.S. (2 Dall.) at 454 (Wilson, J.).

158 Id. at 455 (Wilson, J.).

159 Id. at 465 (Wilson, J.).

160 Id. at 457 (Wilson, J.). Wilson offered the opinion, "[a]s a citizen" rather than "[a]s a judge of this court," that talk about state sovereignty was mistaken in intrastate contexts as well. Id.

161 Id. at 472 (Jay, C.J.).

162 Id. at $472-73$ (Jay, C.J.). Jay, who favored the abolition of slavery, said earlier in his opinion that in the United States "the people . . . are truly the sovereigns of the country, but 
The rationales for Chisholm offered by Jay and Wilson were fundamentally antithetical to discerning any "basis in firm constitutional law" for federalism, and it may be that this aspect of their opinions played some role in Chisholm's swift repudiation by adoption of the Eleventh Amendment. ${ }^{163}$ Certainly, subsequent Supreme Court opinions have avoided direct assertions that the states have no special legal status under American law. ${ }^{164}$ As Part I of this Article suggested, however, from the New Deal to National League of Cities the Supreme Court in effect accepted the Jay/Wilson position by denying the existence of implied federalism limits on national power, a denial substantially revived by Garcia. ${ }^{165}$ It is, of course, precisely this elimination of any legal content to federalism by Jay, Wilson, and their twentieth-century heirs against which Justice O'Connor is protesting. "Federalism," Chisholm or Garcia style, has nothing to do with law.

\section{The Textual Enumeration of Federal Powers}

The most obvious approach to devising a meaningful law of federalism is to take seriously the Constitution's enumeration of federal powers as a definition of what the federal government may, and by implication may not, do. The relevance of the constitutional text to federalism was the centerpiece of one of the earliest pieces of sustained interpretation of the Constitution-Secretary of State Thomas Jefferson's 1791 cabinet opinion on the constitutionality of the national bank bill Congress had presented to President Washington. Jefferson began his argument that the bill was invalid with a list of the state laws that, he alleged, the bill would change or overturn, and then asserted that he "consider[ed] the foundation of the Constitution as laid on this ground: That 'all powers not delegated to the United States, by the Constitution, nor prohibited to it by the states, are reserved to the states or to the people." "166 The means by which Jef-

they are sovereigns without subjects (unless the African slaves among us may be so called)." Id. at 471-72 (Jay, C.J.).

163 On the Eleventh Amendment, see Calvin R. Massey, State Sovereignty and the Tenth and Eleventh Amendments, 56 U. Chi. L. Rev. 61 (1989).

164 Early Marshall Court opinions took special care to show the Court's acceptance of the "special constitutional status" of the states in federal law. Jefferson Powell, Languages of Power: A Sourcebook of Early American Constitutional History 187 (1991).

165 See supra text accompanying notes 2-6.

166 Thomas Jefferson, Opinion on the Constitutionality of the Bill for Establishing a National Bank (Feb. 15, 1791), in Powell, supra note 164, at 42. 
ferson attempted in 1791 to give legal substance to this Tenth Amendment "foundation" was not some notion of "states' rights" but instead a requirement that federal legislation meet a strict test of adherence to the text of Article I. The bank bill, Jefferson wrote, was not justified by the taxing power, ${ }^{167}$ the power to borrow, ${ }^{168}$ the commerce power, ${ }^{169}$ Article I's reference to "the general welfare," essary and Proper Cause. ${ }^{171}$

Jefferson characterized the claim that a national bank would be a useful means toward achieving the purposes of Congress' enumerated powers as a covert argument for congressional omnicompetence. On such reasoning any legislative choice of "means" could be justified, "for there is not one which ingenuity may not torture into a convenience in some instance or other, to some one of so long a list of enumerated powers. It would swallow up all the delegated powers and reduce the whole to one power ...."172 A strict construction of the Constitution's textual definitions of federal power was necessary, Jefferson told Washington, to avoid rendering federalism an empty shell: "To take a single step beyond the boundaries thus specially drawn around the powers of Congress is to take possession of a boundless field of power, no longer susceptible of any definition."173

Later constitutionalists frequently have invoked Jefferson's strategy of using the textual construction of federal powers to create a legally defined area of state autonomy. A familiar example is Hammer $v$. Dagenhart, ${ }^{174}$ the 1918 Supreme Court decision that invalidated a congressional statute banning from interstate commerce products made in contravention of federal child labor standards. The federal

\footnotetext{
167 "[N]o debt is paid by this bill, nor any tax laid." Id.

168 "But this bill neither borrows money nor insures the borrowing it." Id.

169 "To erect a bank and to regulate commerce are very different acts." Id. Jefferson summarily noted that "[s]till less are [the bank bill's provisions] covered by any other of the special enumerations." Id.

170 Jefferson read the expression as defining the purpose of the taxing power. "To consider the latter phrase, not as describing the purpose of the first but as giving a distinct and independent power to do any act they please which might be for the good of the Union, would render all the preceding and subsequent enumerations of power completely useless." Id.

171 The enumerated powers, Jefferson asserted, "can all be carried into execution without a bank. A bank therefore is not necessary and consequently not authorized by this phrase." Id. at 43.

172 Id.

173 Id. at 42.

174247 U.S. 251 (1918).
} 
government defended the statute as a valid exercise of the commerce power, but a majority of the Justices disagreed: "The grant of power to Congress over the subject of interstate commerce was to enable it to regulate such commerce, and not to give it authority to control the States in their exercise of the police power over local trade and manufacture." 175 Because the real purpose and effect of the statute was not to "regulate transportation among the States, but . . . to standardize the ages at which children may be employed in mining and manufacturing," it did not fall within the Constitution's definition of congressional power over commerce. ${ }^{176}$ The Hammer opinion noted that the logical corollary of its interpretation of the meaning of the Commerce Clause was a decision about the scope of state autonomy. The power Congress had sought to employ illegitimately was a power over "a matter purely local in its character, and over which no authority has been delegated to Congress .... Thus the act ... not only transcends the authority delegated to Congress over commerce but also exerts a power as to a purely local matter to which the federal authority does not extend."177 Like Jefferson, the Hammer majority warned that abandoning close judicial scrutiny of the textual legitimacy of congressional legislation would spell the end of federalism as a legal concept. ${ }^{178}$

Hammer v. Dagenhart was right: the consequence of the Court's decision twenty years later to repudiate Hammer's sort of judicial review was the collapse of any functioning law of federalism for four decades (over five decades if one ignores National League of Cities). It might seem puzzling, therefore, that neither National League of Cities nor New York v. United States has proposed reviving textual construction of congressional power as a means of reviving the law of federalism. Why? The answer, I suggest, is that there are, or the Justices perceive there to be, insuperable obstacles to a repristination of the federalism of Jefferson's bank opinion and Hammer.

Historically, the Supreme Court's attempts to limit Congress' reach by textual construction have been sporadic, inconsistent, and unappealing. Exactly the same Court that decided Hammer upheld a fed-

\footnotetext{
175 Id. at $273-74$.

176 Id. at 271-72.

177 Id. at 276.

178 "[T] he power of the States over local matters may be eliminated, and thus our system of government be practically destroyed." Id.
} 
eral statute two years later against a federalism challenge in a remarkably nationalistic opinion by Justice Holmes (who dissented in Hammer). ${ }^{179}$ The whole history of the Court's use of limiting textual construction between the beginning of extensive congressional legislation ${ }^{180}$ and the New Deal repudiation of the enterprise was marked by rapid swings between generous and pinched readings of congressional powers. ${ }^{181}$ Even a sympathetic observer might well conclude that decisions about the proper scope and employment of federal powers are so inherently legislative and policy-driven that even a good-faith judicial attempt to make them inevitably collapses the judicial function into Congress'. Equally important is the social reality that virtually all political groups and persuasions want broad national powers wielded on behalf of their desired objectives. ${ }^{182}$ Thus, it is unlikely that the Court could defy for very long the practical consensus that federal powers should be indefinitely broad even if the Justices wished to do so. Justice O'Connor, at any rate, has carefully avoided any suggestion that she believes the Court should protect federalism by policing the definitional bounds of federal power. ${ }^{183}$

179 Missouri v. Holland, 252 U.S. 416 (1920). Two members of the Hammer majority dissented without opinion in Holland. Id. at 435. Holland is doctrinally distinguishable from Hammer; in the later case Congress clearly was legislating to execute the enumerated federal treaty power, and the only issue was whether there was an implied federalism limit on the treaty power. This doctrinal distinction is, I suggest, superficial: the child labor statute was in terms and in immediate effect a (prohibitory) regulation of certain goods in interstate commerce and nothing more. The limitation to commerce-regulating purposes that the Hammer majority employed was in reality as much a structural inference as the federalism limitation to the treaty power invoked unsuccessfully in Holland. In any event, as Holmes argued persuasively in his Hammer dissent, the Court had repeatedly upheld congressional statutes that obviously or arguably were designed to produce substantive results within the states through the use of commerce regulation. Hammer, 247 U.S. at 278-280 (Holmes, J., dissenting).

180 A good, if somewhat arbitrary starting point for the period of modern congressional activism might be the enactment of the Interstate Commerce Act in 1887. See William M. Wiecek, Liberty Under Law: The Supreme Court in American Life 130 (1988) (discussing Congress' first attempts at creating administrative agencies).

181 Id. at 119-21, 122-23, 127-29, 136-37.

182 Professor Black has referred to "the plain fact that there is as good as no group in the United States that does not want and indeed press for the exercise, in behalf of its own interests, of federal powers that cannot be dreamed to exist except by employment of the expansive modes of interpretation that are now habitual. ... [T] power, expansively construed, are practically infinite in number; the satisfaction of these desires saturates the national government." Black, Constitution, supra note 1, at 477-78.

183 See, e.g., Garcia v. San Antonio Metro. Transit Auth., 469 U.S. 528, 583-85 (1985) (O'Connor, J., dissenting) (discussing with approval the Court's "reject[ion of] its previous 


\section{States' Immunities as Constitutional Rights}

The Constitution's restrictions on governmental power ${ }^{184}$ might be viewed as straightforward corollaries of the limitations on power implicit in the Constitution's textual enumeration of powers. On this reasoning, for example, the First Amendment (redundantly) confirms the fact that the Constitution nowhere grants Congress any affirmative power to abridge freedom of speech. Indeed, ratification-era defenses of the Constitution's lack of an extensive bill of rights often took the position that the purposes of such a bill were already met by the enumeration of powers. ${ }^{185}$ In return, the Anti-Federalists pointed out that the Constitution already contained certain prohibitions on federal actions not affirmatively authorized by the grants of power; such prohibitions were meaningless except on the supposition that Congress could transgress widely held individual liberties in the exercise of its enumerated powers. ${ }^{186}$ Eventually, most Federalists came to share the Anti-Federalists' view, if not their concern. In proposing what eventually became the Bill of Rights to the House of Representatives in 1791, Madison stated that "the powers of the General Government are circumscribed, they are directed to particular objects; but even if Government keeps within those limits, it has certain discretionary powers with respect to the means, which may admit of abuse to a certain extent." ${ }^{187}$ From a very early stage, American courts regularly have treated constitutional "rights" provisions as "trumps"denials to government of the power to act in certain ways or command certain results even if the power is "within th[e] limits" set by constitutional delegations of power. Thus, a second historical strategy for articulating a viable law of federalism has been to discern in the Constitution certain immunities or "rights" protecting states from federal exercises of authority that are within the enumerated powers.

interpretations of the commerce power which had stymied New Deal legislation"); New York, 112 S. Ct. at 2418 ("[T] were phrased in language broad enough to allow for the expansion of the Federal Government's role" to activities that would have been "unimaginable to the Framers.").

184 These restrictions appear in U.S. Const. art. I, $\$ 9$ and amends. I-X.

185 See, e.g., Wood, supra note 103, at 536-43 (discussing the "irrelevance" of a federal bill of rights from the Federalist perspective).

186 For the Anti-Federalist argument, see 1 The Complete Anti-Federalist, supra note 107, at 64-70.

1871 Annals of Congress 455 (Joseph Gales ed., Washington, Gales \& Seaton 1834). 
Despite the prevalence of states' rights rhetoric in the antebellum period, even after John Marshall's death the Supreme Court was reluctant to endorse openly the proposition that an act within the meaning of a textual delegation of power to Congress could be unconstitutional because it violated a state immunity. ${ }^{188}$ The heyday of state-immunities thought as a protection for federalism was the early twentieth century, when the Court on several occasions used the Tenth Amendment or implied federalism principles to invalidate federal legislation. ${ }^{189}$ United States v. Butler ${ }^{190}$ is a classic example of this approach to articulating a law of federalism. Butler involved the constitutionality of the Agricultural Adjustment Act of 1933, which provided subsidies for farmers who agreed to limit their production and thus reduce farm surpluses that it was believed were lowering farm revenues. The Court rejected the Madisonian argument that Congress' power to spend was limited to expenditures in pursuit of objects enumerated in Article I, Section 8, and the majority essentially conceded that the Act's expenditures were within the scope of the "general welfare" requirement. The Court nevertheless held the Act unconstitutional because it transgressed "another principle embedded in our Constitution[:] . . . the reserved rights of the states." 191 The power "to regulate and control agricultural production" was reserved to the states, and thus its proper sphere of operation must be immune

\footnotetext{
188 See, e.g., Mayor of New York v. Miln, 36 U.S. (11 Pet.) 102 (1837), which is a typical example of the ambiguity (or confusion) in the Taney Court's discussion of federalism matters. Justice Barbour's opinion for the Court, by definitional fiat, declared the state law under dormant Commerce Clause review "a regulation, not of commerce, but police." Id. at 132. Although this would seem to dispose of the issue-not being within the affirmative scope of the Commerce Clause, the state law clearly could not violate it in its dormant state-Barbour went on to discuss at great length the state power of "internal police," which he characterized as "complete, unqualified, and exclusive." Id. at 138 (emphasis added). The latter assertion at least suggested that state internal police measures would be immune from federal interference even if the latter were authorized by the Constitution's grants of power, a suggestion perhaps congenial to some pro-slavery Justices concerned about federal interference with slavery. Barbour's remarks, however, may simply be an early precursor of the Court's reasoning in Hammer.

189 Hammer v. Dagenhart, 247 U.S. 251 (1918), indeed could be read as holding that federalism was a basis for striking down the child labor statute wholly independent of the Court's interpretation of the definitional limits of the Commerce Clause.

190297 U.S. 1 (1936), implicitly overruled by Stewart Machine Co. v. Davis, 301 U.S. 548 (1937).

191 Id. at 68.
} 
from federal intrusion. ${ }^{192}$ The Butler majority insisted that judicial protection of the sphere of reserved powers was essential to preservation of federalism; without it the spending power "would become the instrument for total subversion of the governmental powers reserved to the individual states."193

National League of Cities was an attempt to revive the state-immunities-based law of federalism exemplified by Butler. The Court stated that a certain sphere of "traditional government functions" was protected from direct federal regulation-even that within the affirmative scope of the commerce power-by an immunity parallel to an individual's Fifth or Sixth Amendment rights. ${ }^{194}$ But National League of Cities, like Butler before it, was swiftly overruled, and Justice O'Connor's opinion in New York v. United States was careful to negate the possibility that she was invoking a state immunity of this sort. For O'Connor, the law of federalism defines the outer limits of Congress' delegated powers; it does not "trump" federal authority acting within its sphere: "[I]t makes no difference whether one views the question at issue ... as one of ascertaining the limits of the power delegated to the Federal Government under the affirmative provisions of the Constitution or one of discerning the core of sovereignty retained by the States under the Tenth Amendment."195

The Supreme Court's failure to adopt and apply consistently a state-immunities approach as a legal basis of federalism results largely from the same factors that have repeatedly led it to abandon textual construction as a limit on congressional power. Judicial declarations that certain exercises of federal power run afoul of a state immunity, like decisions that hold congressional actions to lie beyond Congress' textual mandate, create a " "sacred province of state autonomy." "196 A state-immunities doctrine thus is equally contrary to the enormous political pressure to employ federal authority to address matters of concern to national political majorities. Similarly, the courts' historical record in employing state-immunities concepts gives little ground

192 Id.

193 Id. at 75.

194 National League of Cities v. Usery, 426 U.S. 833, 841-42, 849-52 (1976), overruled by Garcia v. San Antonio Metro. Transit Auth., 469 U.S. 528 (1985).

195 New York, 112 S. Ct. at 2419.

196 Garcia, 469 U.S. at 554 (1985) (quoting EEOC v. Wyoming, 460 U.S. 226, 236 (1983)). The Garcia majority was of course rejecting a "province of state autonomy" interpretation of state sovereignty. 
for confidence that the approach can be followed consistently or that its results can be distinguished from the imposition of judicial policy preferences. A textual-construction law of federalism obliges judges to reject plausible congressional decisions about the relationship of . given legislation to the effective exercise of an enumerated federal power. ${ }^{197}$ In the same manner, a state-immunities federalism doctrine demands that judges determine which areas of legislative interest "really" matter to the states or lie at the "core" of state sovereignty.

The state-immunities approach suffers from an additional problem not wholly shared by textual construction: it is entirely unguided by constitutional text, ${ }^{198}$ and the inferences it seeks to draw from constitutional structure are equivocal. ${ }^{199}$ Finally, the state-immunities

197 South Dakota v. Dole, 483 U.S. 203 (1987), provides a good example of the problem. Justice O'Connor's dissent was predicated on her autonomy of process principle; she carefully distinguished the state-immunities logic of Butler, in Dole, 483 U.S. at 216, and she explicitly accepted the post-Butler interpretation of the spending power's affirmative scope, an interpretation that she conceded arguendo brought within its sweep the minimum drinking age statute before the Court. Id. at 212-13. But in the process of arguing that the statute was a congressional attempt to coerce state legislative choice, O'Connor addressed the issue of the relationship of the statute as a means to Congress's exercise of its enumerated powers, the same question asked in a textual-construction approach to federalism. "In my view," O'Connor wrote, "establishment of a minimum drinking age of 21 is not suficiently related to interstate highway construction to justify so conditioning funds appropriated for that purpose." Id. at 213-14. See also id. at 214-15 (O'Connor, J., dissenting) (applying over- and under-inclusivity analysis resembling equal protection scrutiny in order to show unreasonableness of relationship).

Even in a post-Holmesian world in which all legal distinctions are matters of degree and judgment, I am unsure how to compare or evaluate this conclusion with the majority's decision that "Congress found that the differing drinking ages in the States created ... [an] interstate problem [that] required a national solution." Id. at 208. Textual construction as a strategy for creating a law of federalism constantly would require the courts to make such contestable judgments in areas in which the post- 1937 federal judiciary have disclaimed special competence.

198 Textual construction limits on federal power, obviously, have available arguments based on the text. As noted above, this probably is of little real significance: A plausible denial of the relevance of most congressional legislation to the enumerated powers almost always would require invocation of some implied limiting principle.

199 It is, I think, a fair structural inference that the Constitution recognizes states with significant governmental autonomy. It is also, in my opinion, a fair structural inference that the Constitution creates a federal government with the authority to meet national problems with congressionally-determined solutions, and that state officials are obliged to execute congressional choices that are within the outer limits of federal authority. How these two inferences are to be reconciled, and what further inferences (the autonomy of process principle, for example) are warranted, seem to me matters that are essentially contestable. Certainly they have been contested throughout our history. 
approach suffers from a historical association with slavery, racial segregation, and ethnic oppression that creates a legitimate concern over its potential implications. Justice O'Connor, in any event, has eschewed the state-immunities strategy in her effort to craft a law of federalism.

\section{Historical Precedent for the Autonomy of Process Principle}

Justice O'Connor's federalism, as we have seen, is not a contemporary restatement of the founders' views, and it does not follow either of the two historically common paths for devising a law of federalism. But this is not to say that her approach is without a historical antecedent. The autonomy of process concept is indistinguishable in principle from a vision of federalism articulated in the second decade of the nineteenth century, most forcefully in the litigation that culminated in Martin v. Hunter's Lessee. ${ }^{200}$

The underlying dispute in Martin v. Hunter's Lessee involved the ownership of land in Virginia. In 1813, the United States Supreme Court held that federal treaties with Great Britain preempted the applicable state laws, and reversed the conflicting judgment of the Virginia Court of Appeals. ${ }^{201}$ The Court of Appeals in turn held that Section 25 of the Judiciary Act of 1789 was unconstitutional and that as a consequence the Supreme Court had no jurisdiction to review state court judgments. ${ }^{202}$ In the final round of the litigation, the Supreme Court sustained the validity of Section 25 and of its jurisdiction. ${ }^{203}$

Martin's holding that the Supreme Court may constitutionally review state court holdings on federal law matters is so foundational an element of the American legal system that it is difficult for us to take rejection of it seriously. The proposition, however, was not incontestable early in the Republic's first century, and the arguments the Virginia judges offered against it were neither illogical nor obviously mistaken. Justice O'Connor's federalism, remarkably and inter-

20014 U.S. (1 Wheat.) 304 (1816).

201 Fairfax's Devisee v. Hunter's Lessee, 11 U.S. (7 Cranch) 603 (1813). The Court of Appeals was the highest civil court in Virginia.

202 Hunter v. Martin, 18 Va. (4 Munf.) 1 (1815).

203 Martin v. Hunter's Lessee, 14 U.S. (1 Wheat.) 304 (1816). 
estingly, appears to be intellectually congruent with this early approach to federalism. ${ }^{204}$

The decision of the Virginia court in Hunter v. Martin ${ }^{205}$ was unanimous, and although the judges delivered seriatim opinions, their arguments reflected a shared vision of federalism. As a practical matter, Judge William H. Cabell ${ }^{206}$ acknowiedged, the ratification-era argument that the activities of the federal and state governments could or would address separate spheres of legislative concern was mistaken. ${ }^{207}$ From the fact that the practical operations of the two systems could not be kept apart, Cabell concluded that federal and state governmental processes had to be entirely distinct if federalism was to have any meaning:

From this position, believed to be incontrovertible, it necessarily results that each government must act by its own organs: from no other can it expect, command, or enforce obedience, even as to objects coming within the range of its powers.

But whilst, on the one hand, neither government is left dependent upon the other, for the exercise of its proper powers, so on the other hand, neither government nor any of its departments, can act compulsively, on the other or any of its organs in their political or official capacities; with the single exception, perhaps, of the case where a state may be sued. In using the term compulsive action, I do not mean to restrain it to the idea of actual force, but to extend it to any action imposing an obligation to obey. ${ }^{208}$

Given his assumption that the federal government's legitimate authority allows it to act in areas that also lie within the substantive sphere of state activity, ${ }^{209}$ Cabell argued that federalism had no legal mean-

204 In saying this, I do not mean to suggest that Justice $O^{\prime}$ Connor is consciously following the views of the critics of Martin or that she questions the validity of Martin's holding about Supreme Court jurisdiction. What is interesting is her independent arrival at a form of constitutional thought originally devised almost two centuries ago.

20518 Va. (4 Munf.) 1 (1815).

206 Because I do not perceive any disagreements among the opinions of significance for our purposes, I shall discuss only Cabell's opinion.

207 "The two governments, therefore, possessing each its portion of the divided sovereignty, although embracing the same territory, and operating on the same persons and frequently on the same subjects, are nevertheless separate from, and independent of, each other." $18 \mathrm{Va}$. (4 Munf.) at 8 (Cabell, J.).

208 Id. (Cabell, J.).

209 Judge Cabell would no doubt be astonished (and horrified) at the scope of federal power regarded as legitimate today, but his reasoning in Hunter, like that of Justice O'Connor in New 
ing unless state governmental processes were immune from federal control. ${ }^{210}$ The practical consequence of evacuating federalism of legal significance, furthermore, would be the emergence of an omnicompetent national government:

[T]o give to the general government or any of its departments, a direct and controlling operation upon the state departments, as such, would be to change at once, the whole character of our system. The independence of the state authorities would be extinguished, and a superiority, unknown to the constitution, would be created, which would, sooner or later terminate in an entire consolidation of the states into one complete national sovereignty. ${ }^{211}$

Judge Cabell, like Justice O'Connor, traced his defense of the autonomy of state processes not only to the general federal structure of the Constitution, but specifically to the original decision to reject the federalism of the Articles of Confederation: "The present government of the United States, grew out of the weakness and inefficacy of the confederation, and was intended to remedy its evils. Instead of a government of requisition, we have a government of power. But how does that power operate? On individuals, in their individual capacities."212

The logic of his federalism argument, Cabell claimed, did not involve any challenge to the supremacy of federal law. The Supremacy Clause, he cheerfully conceded, obligates state judges to enforce federal law as supreme law, "[b]ut it imposes a subjection to the constitution, and to the laws and treaties made under its authority; not a subjection to the Federal Courts." ${ }^{213}$ Nor did his argument involve setting any implied limit to Congress' delegated powers. Under the Necessary and Proper Clause, Cabell argued, Congress is entitled to choose the most efficacious means of executing those powers, subject only to the requirement that its choice "be limited to con-

York, assumes that the sphere of substantive state concerns is open to federal intrusion and preemption.

21018 Va. (4 Munf.) at 9 (Cabell, J.).

211 Id. (Cabell, J.).

212 Id. at 8. (Cabell, J.). Judge Francis T. Brooke's opinion asserted that the practical consequence of allowing the federal government to compel action by state institutions would be to weaken the former as well as the latter: "[T] he government of the United States will operate more feebly in the exercise of its constitutional powers, through organs not directly under its control . ..." Id. at 23 n.(b) (Brooke, J.).

213 Id. at 10-11 (Cabell, J.). 
stitutional means."214 Congress is free, for example, to exercise its power to create lower federal courts and entrust them with jurisdiction over "all the cases of Federal cognizance" by giving defendants the right to remove all cases within Article III to federal court. ${ }^{215}$ Congress thus is empowered fully to achieve its goals, so long as it acts through federal instrumentalities or permits state institutions to enforce federal law through their own independent processes. ${ }^{216}$

The parallel between Justice O'Connor's federalism and that of Judge Cabell and his colleagues is striking and suggests that the modern assumption that John Marshall's opponents have nothing interesting to say is mistaken. ${ }^{217}$ At the same time, however, the intellectual

\footnotetext{
214 Id. at 12 (Cabell, J.).
}

215 Id. at 11, 15-16 (Cabell, J.).

216 Cabell argued that the concern that autonomous state institutions would disobey their obligation to enforce federal law, or do so waywardly, was specious: state dereliction of duty could be followed by a congressional transfer of decision-making authority to federal instrumentalities. Id. at 10-11 (Cabell, J.).

217 In their day, Judge Cabell and his colleagues were not alone in articulating the autonomy of process principle as part of the legal meaning of federalism. The reasoning of Hunter v. Martin actually was anticipated in a decision of the Virginia General Court decided a month before Hunter. See Jackson v. Rose, 4 Va. (2 Va. Cas.) 34 (1815). Jackson may in fact be dependent on Hunter, which was argued the year before. See Hunter, $18 \mathrm{Va}$. (4 Munf.) at 26 n.(c) (Roane, J.) (stating that his opinion was "prepared, and ready to be delivered, shortly after the argument"). The plaintiff in Jackson was a federal revenue collector who sued to collect a penalty due under a federal importation licensing statute. $4 \mathrm{Va}$. (2 Va. Cas.) at 34. The state court held that it could not exercise jurisdiction over the action because to do so would be to usurp the power of the federal government to exercise its authority through its own instrumentalities. Id. at 41 . While the federal government is limited in scope, Jackson stated that "as to all the purposes for which it was created, and as to all the powers vested therein," it is "completely Sovereign," and its "Sovereignty is ... entirely Separate and distinct from the Sovereignty of the respective States." Id. at 37. It was a "notorious" historical fact that "a desire to give Congress a complete and entire control over [federal revenue], was the moving principle which called the present Government into existence." Id. The necessary corollary, according to the Jackson court, was that the Constitution prohibited the involvement of state institutions in the administration of federal revenue laws. The Jackson opinion, like Judge Cabell's in Martin, carefully stressed the obligation of state courts to enforce valid federal rules of law. Id. at 41.

On the United States Supreme Court itself, Justice William Johnson endorsed a version of the autonomy of process principle in his concurrence in Martin v. Hunter's Lessee. Relying on the Court's decision not to remand the case to the Court of Appeals but simply to enter an order itself concluding the litigation, Johnson wrote that Martin left "us, in my opinion, where the constitution and laws place us-supreme over persons and cases as far as our judicial powers extend, but not asserting any compulsory control over the state tribunals." 14 U.S. (1 Wheat.) at 362 (Johnson, J., concurring). The Virginia judges were correct, Johnson continued, in their assertion of "the independence of [state] judicial power"; Johnson believed that American liberty would be at an end "whenever the state sovereignties shall be prostrated 
harmony between New York v. United States and Hunter v. Martin must raise questions about the coherence of Justice O'Connor's federalism with the essentially Marshallian premises of modern constitutional law. The Supreme Court of Judge Cabell's day, after all, rejected the Virginia account of federalism. Although Justice O'Connor assuredly does not question the holding of Martin $v$. Hunter's Lessee, her account of federalism seems in tension with the underlying logic of the Court's opinion in that seminal case.

Writing for the Court in Martin, Justice Joseph Story ${ }^{218}$ attacked the Virginia opinions' logic as circular: "It is assuming the very ground in controversy to assert that [the state courts] possess an absolute independence of the United States. In respect to the powers granted to the United States, they are not independent ...."219 Story identified the heart of the Virginia argument he was rejecting in terms strikingly similar to those Justice O'Connor has used in articulating her federalism. "It has been argued," Story noted, that Supreme Court jurisdiction over state courts:

is inconsistent with the genius of our governments, and the spirit of the constitution. That the latter was never designed to act upon state sovereignties, but only upon the people, and that if the power exists, it will materially impair the sovereignty of the states, and the independence of their courts. ...

It is a mistake that the constitution was not designed to operate upon states, in their corporate capacities. It is crowded with provisions which restrain or annul the sovereignty of the states in some of the highest branches of their prerogatives. ${ }^{220}$

In contrast to Justice O'Connor, Story rejected any essential distinction between the authority of Congress and the federal courts to control state institutions, and noted that "the legislatures of the states are, in some respects, under the control of congress." 221

at the feet of the general government." Id. at 362 (Johnson, J., concurring). On the other hand, the Virginia court's "holding" that $\$ 25$ was unconstitutional and that the Supreme Court lacked jurisdiction over federal-law questions within the section's scope unintentionally betrayed the Virginia federalism principle by claiming for a state institution the power to dictate the processes of a federal instrumentality. Id. at 363-64.

218 Chief Justice Marshall recused himself from both rounds of the litigation because he had a personal financial interest in its outcome. Wiecek, supra note 180 , at 41 .

21914 U.S. (1 Wheat.) at 344.

220 Id. at $342-43$.

22114 U.S. (1 Wheat.) at 343-44. 
Justice Story did not view the central issue in Martin as a narrow textual question about the meaning of Article III and the Supremacy Clause, ${ }^{222}$ although he did give a textual argument for the Court's conclusion. ${ }^{223}$ The controversy before the Court went beyond the specific issue of Supreme Court jurisdiction, important as that issue was, and Story believed the Virginia court's position was as mistaken in its underlying vision as in its actual holding. ${ }^{224}$ Story rejected any account of the Constitution as a careful balance between the sovereignty the states delegated to the federal government by means of the Constitution and the sovereignty they reserved to themselves. The Constitution "was ordained and established, not by the states in their sovereign capacities, but emphatically, as the preamble of the constitution declares, by 'the people of the United States.' "225 Story, unlike Judge Cabell, did not see in the Constitution's grant of direct legislative power to Congress any necessary implication that the Constitution withheld from Congress power to control state governmental processes. The people were as competent "to make the powers of the state governments, in given cases, subordinate to those of the nation" as they were "to invest the general government with all the powers which they might deem proper and necessary."226 Story's Constitution "was to act not merely upon individuals, but upon states; and to deprive them altogether of the exercise of some powers of sovereignty, and to restrain and regulate them in the exercise of others."227

Martin v. Hunter's Lessee and New York v. United States are not, of course, holdings in conflict, and Justice O'Connor is under no obliga-

\footnotetext{
222 In this respect, as in others, Martin contrasts with Justice O'Connor's federalism opinions, which treat decisions such as Testa v. Katt, 330 U.S. 386 (1947), as resting on specific textual provisions rather than broad structural features of the Constitution.

223 "The appellate power is not limited by the terms of the third article to any particular courts. . . . It is the case, then, and not the court, that gives the jurisdiction." 14 U.S. (1 Wheat.) at 338. Taken on its own, this argument is almost silly, since its logic would justify Supreme Court jurisdiction over the House of Lords as readily as over the Virginia Court of Appeals. What makes the textual argument sensible is Story's rejection of the premise of institutional autonomy that the Virginia judges-and Justice O'Connor-accept.

224 As Story noted, "[w]e cannot yield to the force of this reasoning; it assumes principles which we cannot admit, and draws conclusions to which we do not yield our assent." Id. at 343. I have argued elsewhere that the Martin opinion was intended as a "public manifesto" on behalf of the nationalistic constitutionalism of the post-War of 1812 era. Powell, supra note 164 , at 309.

22514 U.S. (1 Wheat.) at 324.

226 Id. at 324-25.

227 Id. at 328.
} 
tion of intellectual consistency either to repudiate New York or to begin voting to deny certiorari to all cases brought in state courts. With those points allowed, however, I believe that she has not as yet carried the burden of justifying her law of federalism by the primary criteria-either original intent or the "consistent" view of the Court over time-that she herself invoked in New York. ${ }^{228}$ The autonomy of process principle O'Connor has articulated was not clearly chosen by the founders; indeed, there is some evidence that the Constitution's proponents expressly rejected the concept. O'Connor's federalism, perhaps for very good reasons, follows neither of the two affirmative approaches to state sovereignty that the Supreme Court historically (if sporadically) has applied. Rather than being an obvious application of the Court's unwavering understanding of the constitutional structure, O'Connor's views seem in conflict not only with modern nationalistic opinions such as Garcia, but also with the logic that led the Marshall Court to reject the closest historical parallel to her views. New York v. United States is a decision that should be evaluated on its own terms, as the embodiment of a vision of federalism that the Constitution permits but does not entail. In the final section of this Article, I address Justice O'Connor's federalism in those terms.

\section{A Prudential Justification for NEW YoRK $V$. UNITED STATES}

The contemporary federal government wields powers so extensive that it sensibly can be viewed as essentially omnicompetent. ${ }^{229}$ This de facto expansion of federal power in the modern era is sanctioned by something approaching a consensus that it is legitimate. ${ }^{230}$ From these observations follows the conclusion that the great ratificationera debate over the meaning of the Constitution is over and the Antifederalists have won: the ultimate practical effect of the Constitution

\footnotetext{
228112 S. Ct. at 2423.

229 This observation sets aside for the present the guarantees of personal liberty and the equal protection requirements that limit federal as well as state power.

230 It seems to be increasingly common for nationalistic constitutional scholars to concede that the nationalistic reading of federal power is a 20th-century innovation. See, e.g., the important new study by Professor Bruce Ackerman, 1 We the People (1991). Although this is not the occasion to discuss that interesting question, I should note that some of the historical scholarship on the ratification era sees in Federalist thought an acceptance of the desirability and inevitability of "consolidation." See, e.g., 1 The Complete Anti-Federalist, supra note 107, at 37.
} 
has been to produce the "consolidated" national government they predicted and feared. Justice O'Connor's federalism is not a nostalgic attempt to reverse this verdict of history: her opinions make no attempt to limit the substantive scope of federal power. The autonomy of process principle of New York v. United States is instead a law of federalism for a fundamentally nationalist legal system. The question addressed in this section concerns why she-or we-should wish to develop such a law.

New York v. United States, I suggest, may be an appropriate decision, and Justice O'Connor's federalism a valuable contribution to American constitutional law, when they are explained along prudential lines. In his extremely valuable typology of constitutional arguments, Philip Bobbitt defines "prudential argument" as the type of constitutional argument that "advanc[es] particular doctrines according to the practical wisdom of using the courts in a particular way."231 "Prudential argument is actuated by facts, as these play into political and economic policies as to which the Constitution is itself agnostic"; it is concerned with "the practical effects of constitutional doctrine." 232

Although prudential argument involves the express consideration of consequences and of policies, ${ }^{233}$ it nevertheless differs from the sheerly political and extralegal prediction of consequences in several respects. ${ }^{234}$ It is legal, constitutional argument in part because it

231 Philip Bobbitt, Constitutional Fate: Theory of the Constitution 7 (1982). Restated in Bobbitt's terminology, the conclusion of the preceding Part of this Article was that Justice O'Connor has not offered persuasive "historical," "structural," or "doctrinal" arguments for New York.

232 Philip Bobbitt, Constitutional Interpretation 17, 16 (1991). Bobbitt's books present the most powerful modern argument about the possibility and the limits of constitutional law as law. See also Philip Bobbitt, Is Law Politics?, 41 Stan. L. Rev. 1233 (1989) (criticizing reductionistic views of legal argument); Philip Bobbitt, Methods of Constitutional Argument, 23 U. Brit. Colum. L. Rev. 449 (1989) (describing the common law methods of argument employed by Americans in interpreting the Constitution).

233 Bobbitt observes, for example, that "arguments over . . . institutional arrangements," which lie at the heart of the prudential modality of interpretation, "are policy arguments." Bobbitt, supra note 230 , at 65 n.19.

234 This claim is, of course, highly controversial, and many prominent constitutionalists vigorously deny that what Bobbitt calls prudential argument can ever be legal reasoning. See, e.g., Robert H. Bork, The Tempting of America (1990). For the purposes of this Article, it is unnecessary to address this important issue in constitutional theory, because as a practical matter the legitimacy of prudential argument is settled by Supreme Court practice. See, e.g., Bowers v. Hardwick, 478 U.S. 186, 194-95 (1986) (curtailing substantive due process doctrine 
derives from the Constitution's "rationalist superstructure of means and ends, of enumerated powers and implied methods, which impose a calculation of benefits."235 Marshall's great opinion in $M^{\prime} C u l l o c h v$. Maryland is the classic example of prudential argument: the Constitution necessarily gives Congress wide latitude in its choice of means, Marshall wrote, because it has entrusted to Congress:

[t]he sword and the purse, all the external relations, and no inconsiderable portion of the industry of the nation .... The power being given, it is the interest of the nation to facilitate its execution. It can never be their interest, and cannot be presumed to have been their intention, to clog and embarrass its execution by withholding the most appropriate means. ${ }^{236}$

The Constitution's textual grants of authority to Congress thus necessarily authorize the exercise of implied powers "calculated to subserve the legitimate objects of that government,"237 and the constitutionality of their exercise depends on the conclusions of such calculation. ${ }^{238}$

$M^{\prime} \mathrm{Culloch}$ also illustrates other aspects of the prudential modality of interpretation. Prudential arguments, properly employed, can be related to other legitimate modalities of constitutional interpretation. The discussion just quoted interweaves prudential with textual and historical considerations. Prudential argument is also unlike (some) extralegal political calculation in that it is concerned with the long-

out of concern over jeopardizing the public legitimacy of the Court); Franklin v. Massachusetts, 112 S. Ct. 2767, 2778 (1992) (upholding governmental action "consonant with, though not dictated by, the text and history of the Constitution" because its results do "not hamper the underlying constitutional goal ... [but] actually promote[ ] it); Planned Parenthood v. Casey, 112 S. Ct. 2791, 2814-16 (1992) (opinion of O'Connor, Kennedy \& Souter, JJ.) (adhering to stare decisis out of concern over jeopardizing the public legitimacy of the Court).

235 Bobbitt, supra note 230, at 230.

236 M'Culloch v. Maryland, 17 U.S. (4 Wheat.) 316, 407-08 (1819).

237 Id. at 411.

238 Marshall's conclusion in $M^{\prime} C$ ulloch that the Court was obliged to give substantial deference to Congress' conclusions on the relationship of implied powers to enumerated federal responsibilities was not intended to suggest that these means-end "calculations" were not of constitutional significance, but only that it was primarily the task of Congress, not the Court, to do the calculating. See, e.g., John Marshall, A Friend of the Constitution (July 5, 1819), in John Marshall's Defense of McCulloch v. Maryland 186 (Gerald Gunther ed., 1969) (explaining that $M^{\prime} \mathrm{Culloch}$ reasoned that "the powers of congress are expressed in terms which ... enable and require the legislature to execute them, and of course, to take means for their execution," and that Congress has the "right" and "duty" to choose the means "most advantageous to the people ... within the limits of the constitution"). 
term impact of particular conclusions on the structures and instruments of government: in $M^{\prime}$ Culloch Marshall stressed "[t]he baneful influence" of the interpretation of congressional power he was rejecting "on all the operations of the government."239 His famous assertion that "the power to tax involves the power to destroy"240 was part of the argument that acknowledging state power to tax a national bank potentially undermined the institutional independence and supremacy of national authority.

The prudential argument for Justice O'Connor's vision of federalism is very powerful. O'Connor's observations in Garcia and New York about the "spirit" of the Tenth Amendment and the federal organization of the Union provide a textual and historical basis for the argument. Even if O'Connor is mistaken about the historical origins of the autonomy of process principle, it is unmistakably the case that the Constitution "looks to an indestructible Union, composed of indestructible States." 241 Unless this constitutional postulate ${ }^{242}$ is wholly formal, the reduction of the state governments to bodies with no independent governmental significance is presumptively contrary to the Constitution. The question of whether a proposed constitutional interpretation satisfies the postulate of federalism, however, cannot be answered on purely textual, historical, or structural grounds. ${ }^{243}$ The same "superstructure of means and ends"244 that demands prudential reasoning in the interpretation of Congress' powers also requires prudential reasoning in the delimitation of the states' prerogatives. ${ }^{245}$

A prudential approach to locating "the boundary between federal and state authority" ${ }^{246}$ requires the constitutional interpreter to give

\footnotetext{
${ }^{239} M^{\prime}$ Culloch, 17 U.S. (4 Wheat.) at 417.

240 Id. at 431.

241 New York, 112 S. Ct. at 2421 (quoting Texas v. White, 74 U.S. (7 Wall.) 700, 725 (1868)).

242 "Behind the words of the constitutional provisions are postulates which limit and control." Principality of Monaco v. Mississippi, 292 U.S. 313, 322 (1934).

243 See supra Part III.

244 Bobbitt, supra note 230, at 230.

$245 \mathrm{New}$ York correctly dismisses the recurrent effort to treat these two constitutional tasks as asymmetric: the duties of "ascertaining the limits of [congressional] power" and "discerning the core of sovereignty retained by the States," $112 \mathrm{~S}$. Ct. at 2419 , are in the end simply different ways of phrasing the $M^{\prime} C$ Culloch obligation of examining the congruity of congressional legislation with the "spirit" of the Constitution.

246 Id.
} 
attention to the consequences, in terms of social policy and, crucially, of long-term effects on American governmental institutions, of a given exercise of federal power. The decline of federalism and the rise of the omnicompetent national government in the United States have brought with them a variety of consequences. Many of these are viewed positively across a broad spectrum of American political opinion: most Americans probably approve of Social Security, the national elimination of de jure racial segregation, and the fundamental concept of federal environmental protection. A legal doctrine of state autonomy that attempted to isolate certain areas of legislative concern and insulate them from national attention would run directly into a widely held and intellectually defensible preference for making federal power at least potentially available to address social concerns. But the elimination of federalism as a legal check on national power also has had less desirable aspects. The nationalization of American government, as one of its chief side effects, has been crucial in rendering democracy increasingly formal, as democracy's traditional corollaries of citizen participation and governmental responsibility become less obviously relevant to the national political process.

Americans tend to be sentimental about "democracy" and nostalgic about earlier eras of supposedly participatory, localized government. Behind the sentiment and nostalgia, however, lurk concerns with substance. Some social and political theorists see in the elimination of mediating structures between the privatized individual and the nation-state Leviathan a profound source of psychological and social alienation and conflict. ${ }^{247}$ It is often argued that various forms of participatory political action, necessarily actualized at the local, community level (if not only there) are badly needed in our society to combat these problems. ${ }^{248}$ "Strong democracy requires unmediated self-gov-

\footnotetext{
247 See, e.g., Christopher Lasch, The Culture of Narcissism (1979); Christopher Lasch, The Minimal Self (1984). Cf. Anthony Giddens, Modernity and Self-Identity 9 (1991) ("Personal meaninglessness-the feeling that life has nothing worthwhile to offer-becomes a fundamental psychic problem in circumstances of late modernity ... [when] systems of instrumental control become more nakedly exposed than ever before."). In his brilliant collection of studies, The Presence of the Past (1989), Sheldon Wolin traces the role of the Constitution and of the Federalists of the 1780s in creating the modern political order of remote and powerful government and isolated and private individuals.

248 See, e.g., Benjamin R. Barber, Strong Democracy: Participatory Politics for a New Age (1984); Giddens, supra note 246, at 209-31 (discussing the concept of emancipatory "life politics").
} 
ernment by an engaged citizenry. It requires institutions that will involve individuals at both the neighborhood and the national level in common talk, common decision-making and political judgment, and common action."249

Meaningful local government requires the existence of the powers of "initiation" and "immunity."2so The power of initiation is the power to develop, consider, adopt, and implement policies that regulate and structure private-sector activities. "Without such powers, local government could hardly affect any private activity,"251 and (we might add) can be of little interest except as a sort of debating society for those with free time. The power of immunity is the authority "to act however [the local governments] wish within the limits imposed by their initiative powers."252 The sort of conscription of state processes with which New York v. United States is concerned denies to the states both initiation and immunity. As Justice O'Connor wrote in her FERC opinion, federal preemption of an area of legislative concern means that "the States may simply devote their resources elsewhere."253 As a result, the states retain the power of initiation in areas Congress has not occupied, and their deliberative processes remain immune from federal control. The imposition of a congressional agenda on state institutions, on the other hand, "drains the inventive energy of state governmental bodies" 254 by commandeering scarce resources of time, attention, and public concern. The states thus become "less able to pursue local proposals"255 because their lack of immunity from federal agenda-setting increasingly denies

249 Barber, supra note 247, at 261. "Strong democracy" is Barber's term for "politics in the participatory mode where conflict is resolved ... though a participatory process of ongoing, proximate self-legislation and the creation of a political community." Id. at 132.

250 The most thorough discussion is in Gordon L. Clark, Judges and the Cities: Interpreting Local Autonomy 67-75 (1985) (identifying and discussing initiation and immunity as two primary principles of local autonomy). Clark's focus is on "local" government in the sense of governmental units below the state level; an underlying theme of Justice O'Connor's federalism is that without some legal doctrine of federalism of the sort she propounds, the states' relationship to the national polity becomes completely analogous to that between municipalities and the states.

251 Id. at 68.

252 Id.

253 FERC v. Mississippi, 456 U.S. 742, 787 (1982) (O'Connor, J., concurring in the judgment in part and dissenting in part).

254 Id. (O'Connor, J., concurring in the judgment in part and dissenting in part).

255 Id. (O'Connor, J., concurring in the judgment in part and dissenting in part). 
them the practical possibility of exercising whatever powers of initiation the national government has theoretically left undisturbed.

Justice O'Connor's federalism does not address all of the negative consequences of national omnicompetence. ${ }^{256}$ For example, New York-style federalism can have no direct effect on the problems that result from the bureaucratic and financial bloating of the national government. New York's law of federalism is of significant value primarily in addressing the unfortunate impact of congressional omnicompetence on local democracy. The autonomy of process principle preserves for state institutions immunity from federal takeover, and thus the power of initiation in areas of concern Congress has not preempted, without challenging the substantive scope of federal power.

Justice O'Connor has always supported her federalism ideas with a set of functional arguments about the value of a robust federal system, although in New York itself, unfortunately, she subordinated these arguments to her debatable historical claims. Some of O'Connor's functional arguments ${ }^{257}$ connect a living federalism to vigorous democracy along lines very similar to those sketched out above:

[F]ederalism enhances the opportunity of all citizens to participate in representative government. Alexis de Tocqueville understood well that participation in local government is a cornerstone of American democracy. . . . Citizens, however, cannot learn the lessons of selfgovernment if their local efforts are devoted to reviewing proposals formulated by a faraway national legislature. If we want to preserve the ability of citizens to learn democratic processes through participation in local government, citizens must retain the power to govern, not merely administer, their local problems. ${ }^{258}$

Justice O'Connor's description of the instrumental value of federalism in nurturing a lively democratic ethos provides the basis for a prudential argument on behalf of the autonomy of process principle as

256 Indeed, as Justice White noted in his New York dissent, O'Connor's approach may provide fewer incentives for Congress to "defer to the wishes of state officials in achieving local solutions to local problems." New York, 112 S. Ct. at 2446 (White, J., concurring in part and dissenting in part).

257 Her most elaborate discussion was in her FERC dissent, 456 U.S. at 787-91 (O'Connor, J., concurring in the judgment in part and dissenting in part). See supra text accompanying notes $42-45$.

258 FERC, 456 U.S. at 789-90 (O'Connor, J., concurring in the judgment in part and dissenting in part). 
a rule of constitutional law. Because political realities exert enormous pressures on both federal and state legislators to accept the continuous expansion of national power, courts are the social institution best suited to serve the Constitution's democratic commitments by preserving some space for local democratic decision making. By doing so, courts serve the ultimate interests of the national polity as well, since the health of national democracy, O'Connor suggests, depends in large part on the continuing importance to Americans of state and local governments.

For those persuaded that this society needs to (re)create a tradition of engaged, participatory politics, there may be "practical wisdom" in "using the courts"259 to check the tendency of a national bureaucracy to subordinate all other public bodies to its own "mobiliz[ation] of administrative power." 260 If there is to be an opportunity in American government for the development of "strong democracy," there may need to be legal techniques by which a space for local agendas, local deliberation, and local decision making can be created and preserved. ${ }^{261}$ Using the traditional lexicon of American politics and law with which judges and lawyers are comfortable, such techniques necessarily must be presented as proposals about the legal substance of "federalism."262 Justice O'Connor's autonomy of process principle is a plausible starting point for crafting one such technique.

\section{CONCLUSION}

The "concept of a legally defined federalism, judicially umpired,"263 has not fared well over time in the United States. Pre-

259 Bobbitt, Constitutional Fate, supra note 230, at 7.

260 Anthony Giddens, The Nation-State and Violence 181 (1985).

261 The role of the courts in the development of "strong democracy," it seems, would have to be limited and defensive. An engaged citizenry and a robust political conversation cannot be created by judicial decree. Some recent scholarship has questioned the assumption that judicial decision making can play a central role in American political and constitutional life without rejecting the importance of judicial review as an element in the constitutional system. See, e.g., Robert A. Burt, The Constitution in Crisis (1992); L.H. LaRue, Political Discourse (1988); Sanford Levinson, Constitutional Faith (1988).

262 Employing this traditional terminology for such purposes is not without its problems: many of the "states" that are the historical and primary referents of federalism talk are part of the problem of remote and nonparticipatory government. A great deal of creative thought and action remains necessary if the language of federalism is to be used effectively to pursue democratic ends. See Clark, supra note 249.

263 Black, Perspectives, supra note 1, at 25. 
New Deal judicial federalism was inconsistent in practice and unsettled in theory; except for National League of Cities, there was no judicial federalism on the post-1937 Supreme Court prior to Justice O'Connor's development of the autonomy of process principle that secured the Court's endorsement in New York v. United States. O'Connor has proposed an answer to "our oldest question of constitutional law" that articulates a judicially enforceable law of federalism without succumbing to the impractical desire to repudiate the modern federal government. This Article has argued that as yet Justice O'Connor has not provided a fully persuasive justification for her vision of federalism, but by the same token she has reopened the discussion along lines that seem promising. If some form of federalism ultimately does come to have a "basis in firm constitutional law,"264 New York v. United States is likely to be seen as its judicial genesis. If a process-oriented law of federalism of the type O'Connor has proposed proves unworkable or undesirable, the answer to the oldest question probably is that federalism, as Professor Black suspected, has no legal substance.

264 Id. 
